\title{
Economics of non-timber forest products (NTFPs) in Oyo-state, Nigeria.
}

\author{
Jonah Ikoku John ${ }^{1}$, Marcus Samuel Nnamdi ${ }^{2}$, Ilori Isaac Aduralere ${ }^{3}$. \\ ${ }^{1}$ (Department of Economics, Achievers University, Owo) \\ ${ }^{2}$ (Department of Economics, Achievers University, Owo) \\ ${ }^{3}$ (Department of Economics, Ekiti State University, Ado Ekiti)
}

\begin{abstract}
This research examines the Economic contributions of major non-timber forest products (NTFPs) to the livelihoods of rural communities in Oyo State for the period covering 2002 to 2004, using descriptive statistics, multiple regression analysis, gross margin analysis, gini-coefficient and normalized profit function analysis. A sample of 150 respondents were interviewed from two forest zones-Ibadan/Ibarapa and Shaki out of four forest zones-Ibadan/Ibarapa,Oyo,Ogbomosho and Shaki zones of Oyo State.

The investigated variables were found significant and bore the expected positive signs thereby showing a direct linkage with gross income i.e.an increase in these variables brought about an increase in income.The gross margin analysis shows that NTFPs trade in the study area was profitable with an average trader earning a gross margin of N8,827.64 per month. The gini-coefficient of 0.95 shows inequality in income distribution.

The normalized profit function analysis shows that for Bush meat, there is equal economic efficiency in both rainforest and savannah zone respectively. However savannah NTFP, users do not have absolute price or allocative efficiency. In the case of fuel wood there is no equal economic efficiency in both rainforest and savannah zone whereas NTFPs users in the savannah have absolute allocative or price efficiency. The implication is that for both types of NTFPs there is profit maximization i.e the users equate the value of marginal product of their variable factors of production to their factor cost. Also fuel wood is sustainable in the savannah zone and government should encourage the sustainable development of forest trees through afforestation projects.
\end{abstract}

Key words: Non-timber forest product (NTFPS),Normalized profit function,gini-coefficient,gross margin analysis.

\section{Introduction.}

Millions of people around the world depend on forests for medicine, raw materials, fuel, income and food. Food and Agricultural Organisation (FAO) estimates that 500 million people live in or near forests, and in some places, forests are the primary source of food. But almost everywhere, forests provide regular supplements to people's diets. In many developing countries, forest foods represent a much needed safety net, helping people get by between harvest seasons, when crops fail or during times of droughts, famines or social strife. In some areas, forests support livestock production by providing fodder, and in others for example, coastal mangrove swamps - they support local fisheries.

Beyond these direct contributions for food security, the environmental services provided by forests play a critical role in ensuring sustainable agricultural production. Forests and woodlands help filter and maintain water supplies, protect against soil erosion and land degradation, moderate climate and slow global warming by removing carbon dioxide from the atmosphere. Forests are also rich deposits of biological diversity and provide large number of poor people with fuel for cooking food and heating their homes, while forest-based employment gives many others a source of cash income. The forests apart from providing timber also provide biological products called non-timber forest products (NTFPs). The term non-timber forest products (NTFPs) and similar terms like 'minor', 'secondary' or 'non-wood forest products' (NWFP) have emerged as umbrella expression for the vast array of both animal and plant resources other than wood (or timber, in the case of 'non-timber), derived from forests or forest tree species. The term 'non-timber forest products' is used by the Food and Agricultural Organization of the United Nations (FAO), and it refers to all plants and animal products derived from wild-sources and collected on forest lands and/or from forest species. NTFPs can also be gathered from semi- domesticated plants in plantations or in agro forestry schemes, or can be produced in intermediate production systems of varying degrees or domestication. In any case, their wild or semi-domesticated status distinguishes them from well-established agricultural crops such as oil palm, cocoa, coconut, rubber or coffee. Non-timber forest products have attracted considerable global interest in recent years due to an increasing recognition of their contribution to household economies and food security, and to environmental objectives, such as the conservation of biological diversity.The World Health organization estimates that some 80 percent 
of the population of the developing world use NTFP for health and nutritional needs. Several million households worldwide depend heavily on these products for subsistence consumption and/or income. Some NTFPs also provide raw materials for large sale industrial processing, including for internationally traded commodities such as foods and beverages, flavourings, perfumes and medicines. Presently, at least 150 NTFPS are significant in terms of international trade, for example, (1) honey, (2) gum arable, (3) rattan, (4) cork, (5) forest nuts and (6)mushrooms, (7) essential oils, and plant or animal parts for pharmaceutical products.

\section{Literature review.}

Food and agricultural organization [1] observed that a proportion of the world's total Africa represents nearly 23 percent of the land area, 13 percent of the population, 15 percent of forest and around 5 percent of forest population. The area of forest per capital ( $0.7 \mathrm{ha})$ in Africa is higher than that of Asia ( $0.1 \mathrm{ha})$ but low compared to Europe $(1.3 \mathrm{ha})$, North, Central and South America having a total of 3.7ha. Africa also has important wildlife resources. This can support significant social and economic development, but until now a variety of indicators has shown Africa to make only modest progress in the sustainable development of its forest resources.

Geographically about 97 percent (505 million) of Africa's forest cover is found in tropical Africa and is distributed as follows: Central Africa (205 million ha.); East Saharan Africa (58 million ha); Moist West Africa (40 million ha); Insular Africa (15 million ha); the remaining 30 percent that is, (15 million ha) is found in North Africa and Non-Tropical Southern Africa [2].

Overall, the forest covers an area of 520 million hectares, equivalent to almost 18 percent of the land area of Africa. With the exception of North Africa and Non-tropical South Africa, the Continent contains the world second largest reservoir of tropical South Africa, the Continent contains the World second largest area of desert climatic zone than any other continent except Australia. From this point of view, Central Africa and West Africa contains most of the dense forest in the continent, however FAO, 1995 points out that Africa forest face considerable threat such as rapid conversion into agricultural lands, overgrazing, wild life, over logging, fuelwood and charcoal production, hence the need to study potentials of forest and non-forest resources to rural and urban welfare. Forestry in Nigeria as in many other respect is a situation of contrast as it occur in the Africa continent where we have some state having very rich forest, others are dry deserts and severely lacking in forest cover yet others have only a modest natural forest environment which permits mainly subsistence usage. A number of state have compensated for the lack of natural forest by establishing forest plantation. However, some states are yet to realize this, that the potential offered by wild life resources remain largely utilized.

Forest as a renewable resource is capable of growth and regeneration. Forests are capable with sound management of producing products and services that are very vital to economic growth and development as well as producing food for the daily living of people. Forest and forest industries contribute to the economy through the production of and trade in wood for energy, sawed wood, panels and papers. Estimate of the value of forest products is given to be worth US $\$ 400$ billion in 2000 by FAO in Nigeria, of which $1 / 4$ was in the form of fuel wood and the balance as the value of forest product in Industrial use. Other minor products of the forest are Kenaf, Jute, flax, fibre, Resins and dyes, gums, wild fruits, mushrooms, and edible fungae, cork, honey, bush meat, herbs and medicines etc. These are important in the sustainable sector as well as raw materials for the Industrial sector. The value of export of forest product was US \$ 105 billion in the 2000, a little over 3 percent of world's merchandise trade. The forest and forest industry plays considerable roles in producing "services" necessary for sustainable development of the environment. They fulfill environmental functions of soil and water conservation and the conservation of biodiversity. The products of the forest and forest industries are generally environmentally beneficial. They have potential of being recycled in production or in energy generations and the industries themselves have potentials for high energy efficiency and low negative impact on air and water quality.

Large number of species occurs throughout the different ecological zones of the country. The prevalence of any particular species in any ecological or geographical zone depends on such factors as the climate, terrain, land use practices, past use and misuse as well as forest management practices. Thus, fire tender species and species requiring high humidity and high rainfall are more common in the humid lowland region of the country while fire-tolerant, drought, and high temperature resistant species are peculiar to the drier savannah region. 171 species of NTFPs is listed in South Nigeria, while [3] listed about 50 species in Omo Forest Reserve, Southern Western Nigeria. Species such as Andasonia digitata, Tamarindus indica, Acacia spp; Prospsin Africana, parkia biglobosa, Phoenix reclinata, Hibiscus sabadarifa, Zingiber officinale, Vitellaria paradoxum, AlliumSatirum are found mainly in the savannah ecosystem of the North. In the southern forest regions, such as Aframonum melegueta, xylopia aethiopica, piper guineense, Blighia sapida, Tetra pleura tetraptera, kola hispida, mormodica anagusiticephales, aArtocarpus artilis, Dacryodes edulis and Irvingia spp. among many others are prevalent. Although, the occurrence of the various species of NTFPs are peculiar to specific geographical and ecological zones of the country; their uses cut across the different regions. 
Furthermore, the names given to and the uses to which the various NTFPs are put vary across the different ethnic and ecological regions. The contribution of these resources to the well-being of the people is easily discernible in the following areas of human endeavor.

Forests contain many useful animals of subsistence and commercial values which sustain rural people and rural economies. According to [4], the consumption and trade in these goods and services are not properly documented and were thus tagged "Minor forest products". This grossly underscores the enormous socioeconomic and cultural significance of these resources and hence the failure of policy makers to take their sustainability very seriously. Recently, however, forest managers seem to have realized the enormity of the contribution of these resources to the welfare of the people, particularly in the rural areas. The name has thus been changed to "Non-timber forest products" .[5] defined Non-Timber Forest Products (NTFPs) as the forest goods and services excluding commercial timber. In this context, NTFPs include such diverse products as animals, leaves, local building materials, medicinal plants, forest foods, sponge, chewing sticks, fibres, gums, rattan and canes among others. These products according to [3] constitute rural industrial raw materials for cottage and brewing of local wines and beers. They are also used as cultural symbols, ritual artifacts as well as medicines. Despite the huge contribution of these resources, the sector has been taken for granted for a long time. They have thus been subjected to misuse, overuse and gross undervaluation.

In Nigeria, there are many of these products in use and their occurrence and prevalence vary among the major ecological zones of the country. In the past three decades, these NTFPs have attracted greater attention of scientists in Nigeria. Prominent scientists have carried out research on the prevalence, prioritization, socioeconomics, genetics and domestication of many of these species. Notable among these are studies by [6] [7] [8] [9] [10] [11] 12] Okafor's Studies focused mainly on edible indigenous fruit plants and their importance in rural economy. Egunjobi studied the unexploited plant resources of Nigeria. Ladipo worked on collection and conservation of the genetics resources of Irvingia gabonensis in West and Central Africa while Popoola and Oluwalana studied the marketing of Non-Timber Forest Product in Nigeria.

Despite all these efforts, NTFPs are still not receiving the adequate attention they deserve from policy makers. Hence, many of the Non-Timber forest products are becoming scarce, threatened, endangered and extinct in extreme cases. Many factors are responsible for this. They include, demographic pressure, recklessness on the parts of managers and users, undervaluation, obsoleteness of management plans and urban and industrial development. In order to ensure sustainability of these products; there is need for planned management and utilization as well as conservation of the resources [14].

Food is one of the most basic needs of man. In Nigeria, NTFPs contribute substantially to household food security particularly during the periods of food scarcity (hungry season). Various fruits, seeds and leafy vegetables are eaten directly without cooking. Examples of these include Vitellaria paradox; Annona esculents; Blighia saplds; Andansonia digitata; Magnifera indica; Sponchas mornbin; Chrysophyllum albidum; Synsephahum dulcificum and many others. Many other forest species are harvested and marketed for their fruits, leaves or even roots which are used as food supplement, spices or condiments after partial processing, boiling, roasting or cooking. Examples of these include: irvingia gabonensis; I. wonbuli; Dacryodes edulis; Artocarpus attilis; piper guineese; Tetrapleura tetraptera; Aframonum melegueta; monodora myristica; Tamarinds indica; vitex doniana; Adnasonia digitals; Bombax breviscupe; treculia Africana; Phikenetia conephora, piper unbelation; celosia argentea; Amaranthus sp; Sesamum indicum; sesamum radiatum; celosia laxa, Crassocepha Illummbera; occimum spp; Veronia amygdalina; edible mushrooms and a host of others. Furthermore, wild games and fish constitute the major animal protein intake of rural Nigerians. Animals such as Cephalophum sylivcultor; kobus elioppiprymus; Hippotragus equines; kobuskobi; Tragelaphus scrptin; Cephalophus monicola and birds such as Senegal coucal; Bush fowl, Francohnus bicalcaratus and Numeda meleagriare cropped for household consumption and for commercial purposes. Insects are also consumed in parts of the country and these include palm worm, Termite (green) locust, crickets, and catterpilla of cirina butrewspermii.

In addition to supplementing human dietary needs, the largest portion of animals (wild and domestic) food is provided by forest plants. Species such as fuldherbia albida; Gliricidia sepium; Leuceana leucocephala; calliandra spp; Securidaca longgepe dunculate; Rotteboellia exaltat; panicum maximum, tridax procubens, Androlpogon gayamus; Andropogin tectorum; and fed to domestic animals or roaming and grazing animals allowed to feed in any of them in the world. Wild animals pointed out. It is quite obvious that the forest plants and animals contribute enormously to the household food security food in Nigeria as in many other developing countries.

It is difficult to measure precisely the proportion of household income which comes from NTFPs because forest based activities are closely interwoven with farm activities (Arnold, 1994). It is however, indisputable that they contribute significantly to both the household and the general economy. Individual contribution of each NTFPs may be little but collectively they contribute significantly to the rural economy and can add to export revenues. Many income generating activities in the rural areas are based specifically in the 
NTFPs. According to Egunjobi, NTFPs contribute to the rural economy as much as, if not more than timber products. Activities such as mat-making, cane, furniture production, fuelwood sales, pestle and mortar and wood craft fetch a lot of money to rural households. sales of leaves of various species earlier enumerated, chewsticks from various species, sales of fruits and seeds of all kinds, Bushmeat, snails and fish in rural and urban markets also generate a lot of income. Trades in gum Arabic from Northern Nigeria, as far as Niger Republic across Nigeria border to Europe and Asia runs into several millions of Naira annually. Sales of medicinal species such as Enantia chlorantia; Garcinia kola, piper guinense; Harungana madagascariensis; Alstonia boonei; morinda lucida; Aframonum meleguenta; Tetra pleura tetraptra and several others are traded at local and urban markets even across the borders to Ghana Rpublic of Benin and other neighbouring countries. Fruits such as Dacryodes edulis; Irvingia spp; Parkia bighobosa and phonerux reclimata are traded all over the country and they fetch the people a lot of money. The income generating capacity of the resources can be further enhanced if proper management strategies are applied.

Forests play a significant role in all aspects of cultural [5]. While some forest species are perceived positively as protechtion or providers, others are viewed as being scared and to be feared. There are scared and forbidden forest where entry and/or utilization of resources are restricted. In Yorubaland or Nigeria for instance, "Igboro", Igbo Igbale" are highly scared. All these are borne out of the cultural beliefs of the people about the forest. Some forests are feared by man and are specifically used for rural purposes. Only the elders and priests of particular gods/goddesses can enter such forests. Wood is carved into various statutes which symbolize different gods/goddesses and twins and these are worshipped as intermediaries to the supreme God. Furthermore, various animals skins; skulls and birdsheads are used in decorating masquerades in Southern Nigeria. In traditional chieftaincy, the leaves of newbouldia leaves is an important item used in the rituals performed during installation ceremonies. Traditional chiefs used bird's feathers to decorate their caps in Igboland.

Many other species feature prominently in the tradition of many people. The Ogun (god of iron) worshippers in south=-western Nigeria, worship certain species of snakes while Garcinia kola is an important item in the ritual performed to appease the god of thunder (Sango, Yoruba) whenever he is angry snails are used to worship the god of land (orisaala) while kola reticulate and Aframomum melegueta are used in many ritual sacrifices and traditional ceremonies throughout the country. Certain tree splecies are also worshipped directly. Examples of these include: milicia excels; ceiba pentandra and Andansonia chqitata.

According to [13], individual species of plants and animals have spiritual significance in many societies; such species can therefore, not be used at all or are used for particular purposes. Honey-bee worshipping is a big annual event at Ikoyi-Ile, Oyo State of Nigeria. The voices of certain animals and birds are associated with certain natural occurrence e.g the distress cry of chameleon. Chameleon is believed to attract thunder strike while the voice of birds Senegal coucal is believed to attract rainfall in Yoruba land.

Rural non-farm work accounts for a substantial proportion of the rural employment. In surveys carried out in southern in Eastern Africa, it was revealed that forest products enterprises account for sixteen per thousand in the population. In the high forest zone of Southern Ghana, [5] reported that 68 percent of the rural forest households surveyed were involved in rural Nigerians, forest related activities contributed significantly to rural employment in the country. Activities such as game hunting, local fishing, leaves, fruits, seeds, fuelwood harvesting and processing are very important when farm works are light and scanty. In southwestern Nigeria, forest based rural industries such as wood crafts, cane furniture, pestle and mortar production, fabrication of tools handles and chew sticks provide employment for large number of people who are involved in either in harvesting, processing or marketing of these products. Leaves used in wrapping food, preservation and cooking are still very much in use in the Southern parts of the country. Such leaves incude, Halia alials, tectona grandis; thaumatocucus danielli, megaphyrynium macrostachum; maranthodea leucantha; Nauclea latifolia; daniellis oliven; Mucuna provide employment for rual women while other women in major towns such as Ibadan, Oyo, Ondo Ile-Ife, Ota, Abeokuta, are involved in their marketing, wood energy production and marketing also provides rural employment particularly during the dry season. The major forms of woods energy used in Nigeria are fuelwood and charcoal. Both in the Northern and Southern parts of the country, these items involve both men, women and children in the gathering, processing and marketing all year round. The role played by NTFP, in the provision of rural employment is very crucial and requires robust analysis.

Until recently, forest development programmes have focused upon only trees and their industrial uses, rather than the local population and its dependence upon both timber and non-timber forest products for households food and economic security. To a large extent, rural inhabitants, particularly women have remained at the ;"hunters and gatherers" stage of development as far as forest products are concerned. There has been limited attempt to integrate the users of these products into a programme of forest regeneration and conservation. Unfortunately, rural women have generally not been considered to ba an important part of the solution to sustainable development and utilization of forest areas, but rather viewed as exploiters from whom the forests must be protected. 
Declining access to forest resources due to deforestation, increasing competition, government restrictions and so on, has had an adverse effect upon the majority of poorer rural households in general, and rural women in particular. The impact of diminishing resources, lack of involvement in development activities, and the constraints and potentials for women's participation in development strategies, however, are not the same for all rural women. Great variability in rural women's dependence upon and utilization of forest products exists based upon ecological, ethnic and socio-economic difference, and the degree of pressure upon the land.

Presently, in many countries of the world, rural women are still caretakers and users of forests. They have a vital role in environmental management and development. Their full participation is therefore essential to achieve sustainable management. Women's widely recognized role in forestry sector as labourers, collectors, users and processors of non-timber forest products (NTFPs) and workers in small scale forest based enterprises, totally ignore their need and priorities, as well as their entailment to benefits. While women in developing nations normally have multiple often disproportionate responsibilities, they have little ownership or control over productive resources. This imbalance in the ownerships and control over resources place women in a subordinate and disempowered position relative to men as they are forever dependent.

Thirty percent $(30 \%)$ of today's forestry professionals in the U.S. forest Service (with 28,000 employees) and $20 \%$ of the supervisors are women as compared to $1 \%$ in 1976 . There are rising executives in multi-nation wood and paper companies, in international environmental organizations and in trade associations.(Madhu Sarn,1998).

Women in developing countries are also identifying sacred forests to meet household needs- forests that are off-limits to timber extraction. They are planting trees to stabilize soils and hillsides and produce more forest products. They are creating new nurseries and establishing green belts and shelter belts. It is clear that given a chance, rural women in the world over will act to conserve forest resources and ensure a long term supply of the forest goods and services they depend on every day(Stephanse Caswell,1988). Evidently therefore, gender equality needs be integrated into participatory forest management from the stage of conceptualizing policy through to detailed planning, designing of institutional mechanisms to implementation and monitoring and evaluation. Before this, the need to assess the present situation becomes imperative.

\section{Study Area And Data.}

\section{1 study area.}

The area of study is Oyo State. The state is chosen due to the prevailing climatic and soil characteristics. Three vegetational zones are identifiable. These are forest, savannah and the derived savannah. Oyo State is bordered by Benin Republic in the west, in the North and East by Kwara and Osun States respectively and by Ogun State in the South.The state as it is presently constituted came into being in August 31, 1991 when the state creation excised the present Osun State from the old Oyo State. It covers a land area of 27,000sq kilometers and made up of 33 local Governments in four Agricultural zones of Ibadan/Ibarapa, Oyo South and Shaki and three senatorial districts namely Oyo Central, Oyo South and Senatorial Districts.

Oyo State is located between $7^{0} 3^{1}$ and $9^{0} 12^{1}$ North of the equator and longitudes $2^{0} 47^{1}$ and $4^{0} 23^{1}$ East of the meridian

\subsection{Sources of data.}

The study made use of both primary and secondary data. The instrument for collecting the primary data was structured questionnaires. The data collected include data on the socio-economic characteristic of individuals involved in NTFPs gathering, processing and marketing such as age, gender, educational level, household size, marital status income level, off farm activities, expenditures etc. Secondary data were obtained from Forestry Department of ministry of Agriculture Secretariat Ibadan and their zonal offices at Onigambari, Shaki, Ibarapa, Forest Research Institute of Nigeria (FRIN) Ibadan, Nigeria Institute for Social Economic Research (NISER) Ibadan, Department of Forest Resources Management University of Ibadan, International institute for Tropical Agriculture (IITA) Cocoa Research Institute of Nigeria (CRIN), Center for Environment, Renewable Natural Resources Management (CENRAD) and Journals were used to supplement the primary data collected.

\subsection{Emperical approaches.}

The following analytical techniques were used in the study.

\subsubsection{Regression analysis.}

The summary variables used in the regression analysis includes

$Y_{i}=\beta_{0}+\beta_{1}+\beta_{2}+\beta_{3} X_{3}+\beta_{4} X_{4}+\beta_{5} X_{5}+\beta_{6} X_{6}+\beta_{7} X_{7}+\beta_{8} X_{8}+\beta_{9} X_{9}+\beta_{10} X_{10}+\beta_{11} X_{11}+\beta_{12} X_{12}+\beta_{13} X_{13}+\beta_{14}$ $\mathrm{X}_{14}+\beta_{15} \mathrm{X}_{15}+\beta_{16} \mathrm{X}_{16}+\beta_{17} \mathrm{X}_{17}+$ ei------------(1)

Where $\mathrm{i}=1,2,3, \ldots \ldots \ldots . \mathrm{n}$ 
$\mathrm{Y}_{\mathrm{i}}=$ Income from trade in NTFPs in naira

$\mathrm{X}_{1}=$ Age in years

$\mathrm{X}_{2}=$ Family size

$\mathrm{X}_{3}=$ Income from non NTFP trade in Nigeria

$\mathrm{X}_{4}=$ Expenditure in NTFP trade in Nigeria

$\mathrm{X}_{5}=$ Educational dummy variable $=1$, if educated, 0 if otherwise

$\mathrm{X}_{6}=$ NTFPs source (Free areas or forest reserves)

$\mathrm{X}_{7}=$ Ecological zone (Rainforest or savannah)

$\mathrm{X}_{8}=$ Sex dummy variable $=1$ if male; 0 if female

$\mathrm{X}_{9}=$ Marital status dummy variable $=1$ if married; 0 if otherwise

$\mathrm{X}_{10}=$ proximity to the source of NTFPs

$\mathrm{X}_{11}=$ Experience in years

$\mathrm{X}_{12}=$ Religion dummy variable $=1$ if Christian; 0 if otherwise

$\mathrm{X}_{13}=$ Major occupation e,g. farming, trading etc.

$\mathrm{X}_{14}=$ Major NTFPs in the study area whether bush meat or fuel wood or wild fruits etc.

$\mathrm{X}_{15}=$ Quantity of major NTFPs harvested in kilogramme

$\mathrm{X}_{16}=$ Price of major NTFPs in Naira

$\mathrm{X}_{17}=$ Seasonality dummy variable $=1$ if rainy; 0 if otherwise.

\subsubsection{Gross margin analysis}

The gross margin of an enterprise is the difference between the total value of production and the variable cost of production. The gross margin analysis was used to determine the profitability of NTFPs in the study area.

$\begin{array}{rll}\text { GM } & = & \text { GI - TVC--------------(2) } \\ \text { Where GM } & = & \text { Gross margin } \\ \text { GI } & = & \text { Gross income } \\ \text { TVC } & = & \text { Total variable cost }\end{array}$

\subsubsection{Gini Coefficient analysis}

The gini coefficient was used to determine the inequality in income in the Non- timber forest products trade. The gini coefficient is calculated with the formula.

$\begin{array}{lll}\mathrm{G} & = & 1-\Sigma\left(\mathrm{X}_{\mathrm{i}}+_{1}-\mathrm{Xi}\right)\left(\mathrm{Y}_{\mathrm{i}}-\mathrm{Y}_{\mathrm{i}}+1\right)-----------(3) \\ \text { Where } & \mathrm{X}_{\mathrm{i}}= & \text { Cummulative percentage of respondents } \\ \mathrm{Y}_{\mathrm{i}} & = & \text { Cummulative percentage of income }\end{array}$

\subsubsection{The normalized profit function}

The model employed for the normalized restricted profit function analysis is a variant of the Yotopoulous and Lau (1972) and Adesina et al (1997) model. In the model the Zellner's seemingly unrelated regressions estimation (SURE)) procedure was employed to jointly estimate the profit function equation with the factor share equations. It also employed some restrictions in order to test the hypotheses stated in the study. Given the production function of the form.

$\mathrm{Q}=\mathrm{f}\left(\mathrm{X}_{1}, \mathrm{X}_{2} / \mathrm{X}_{3}, \mathrm{X}_{4}\right)$

$\mathrm{Q}=$ total quantity of output

$\mathrm{X}_{1}-\mathrm{X}_{2}=$ Vector of quantities of variable inputs

$\mathrm{X}_{3}-\mathrm{X}_{4}=$ Vector of quantities of fixed inputs

The first order condition for the maximization of profit with respect to variable inputs is: $\delta \pi \delta \mathrm{X}=\mathrm{q}_{\mathrm{j}}^{*}$ $. . \mathrm{j}=1$,

where $\mathrm{qj}^{*}$ is the normalized price of the jth variable input i.e. norminal price of variable input/price of output. The demand for the jth variables input of the profit maximizing farm can be solved from equations (ii)

$\mathrm{X}_{\mathrm{J}}{ }^{*}=\mathrm{f}_{\mathrm{j}}\left(\mathrm{q}_{\mathrm{j}}{ }^{*}, \mathrm{X}_{3}, \mathrm{X}_{4}\right)$

where $\mathrm{X}_{\mathrm{J}}^{*}$ denotes the optimal quantity $\mathrm{jth}$ of input and $\mathrm{q}_{\mathrm{j}}{ }^{*}=$ vector of normalized prices of the variable inputs.

Restricted profit is then defined as:

$$
\pi=P Q=\sum_{j=1}^{m} q j X j
$$

Where $\mathrm{P}=$ price of output

$\mathrm{Q}=$ quantity of output 
That is, total value of output less the total cost of the variable inputs of production equal the profit. Hence, restricted profit is equivalent to the surplus appropriated by the fixed inputs of production.

Substituting equation (i) and equation (iii) into equation (iv), profit can be expressed as a function of normalized prices of the variable inputs and the quantities of the fixed inputs.

$$
. \pi=P_{0}\left[F \left(\mathrm{f}_{1} *\left(\mathrm{q}_{\mathrm{i}} \mathrm{X}_{1}\right) \ldots\left(\mathrm{f}_{\mathrm{m}} *\left(\mathrm{q}_{\mathrm{i}} \mathrm{X}_{6}\right)-\sum^{\mathrm{n}} \mathrm{q}_{\mathrm{j}} \mathrm{f}_{\mathrm{j}} *\left(\mathrm{q}_{\mathrm{j}} * \mathrm{X}_{4}\right), \mathrm{q}_{\mathrm{j}} * \mathrm{X}_{5}\right)\right.\right. \text {. }
$$

Normalized restricted profit $\pi^{*}$ is thus given by

$$
\boldsymbol{\pi}^{*}=\boldsymbol{\pi} / \mathrm{p}=\mathrm{f}^{*}\left(\mathrm{q}_{\mathrm{j}}^{*}, \mathrm{X}_{4}, \mathrm{X}_{5}\right)
$$

Assuming the use of Cobb Douglas production function with homogenous degree of one, then $\boldsymbol{\pi}^{* *}=\mathrm{A} * *{ }_{\mathrm{j}=1}^{\mathrm{m}} \boldsymbol{\pi} \mathrm{p}_{\mathrm{j}}{ }^{* \mathrm{ajn}} \boldsymbol{\pi}_{\mathrm{j}=1} \mathrm{z}_{\mathrm{j}}{ }^{\beta \mathrm{j}}$

where $\alpha_{j}{ }^{*}, \beta^{*}$ and $\mathrm{A}$ are parameters to be estimated.

The Cobb-Douglas functional form was fitted for the farm profit equation. The model of the farm profit equation fitted for this study is of the form:

2

In $\pi^{*}=\operatorname{In} \mathrm{A}^{*}+\alpha_{\mathrm{LB}} * \operatorname{Inq}_{\mathrm{LB}}+\alpha_{\mathrm{FU}} \operatorname{Inq}_{\mathrm{FU}} *+\beta_{\mathrm{XT}} * \operatorname{In} \mathrm{X}_{4}+\beta_{\mathrm{LD}} * \ln \mathrm{X}_{5}+\Sigma \mathrm{d}_{1} \mathrm{D}_{1}$

where:

$$
\mathrm{i}=1
$$

$A^{*}, \alpha j^{*}, \beta j^{*}$ are parameters to be estimated.

$\mathrm{q}_{\mathrm{LB}} *$ Normalized price of labour input.

$\mathrm{q}_{\mathrm{Fu}^{*}}=$ Normalized price of fuel input.

$\mathrm{X}_{4}=$ Capital used to purchase fixed inputs like cutlass and other farm implements in naira.

$\mathrm{X}_{5}=$ Size of land cultivated in ha.

$\mathrm{D}_{1}=$ Dummy variable for ecological zone $0=$ savannah; 1 = Rainforest

$\mathrm{D}_{2}=$ dummy variable for sex $0=$ male; $1=$ female

By Shepherd Lemma (1955), differentiation of the normalized profit function with respect to normalized price of the $j^{\text {th }}$ variable input gives the demand function of the $j^{\text {th }}$ variable input.

Actually the demand for each variable is

$$
\mathrm{X}_{1}=-\delta \pi / \delta \mathrm{q}_{\mathrm{J}}(\mathrm{LB}, \mathrm{FU})
$$

Which implies the following factor share functions

$$
\begin{aligned}
& -\mathrm{q}_{\mathrm{LB}} \mathrm{X}_{\mathrm{LB}} / \pi^{*}=\alpha_{\mathrm{LB}}{ }^{*} \\
& -\mathrm{q}_{\mathrm{FU}} \mathrm{X}_{\mathrm{FU}} / \pi=\alpha_{\mathrm{FU}}
\end{aligned}
$$

where $\mathrm{X}_{\mathrm{LB}}=$ total labour in mandays

$\mathrm{X}_{\mathrm{FU}}=$ total quatity of fuel used in litres.

\subsubsection{Hypotheses Testing}

Hypothesis 1,2,3,4,5, and 6 were tested using Zellner's method with restrictions. In this regard, the seemingly unrelated regression estimation procedure in which there is a joint estimation of the normalized profit function with the factor share equations for variable inputs with restrictions.

Hypothesis 1: This was to test for equal economic efficiency (technical and price or allocative efficiency) in profit for the different ecological zones. This was done by testing with the restriction of the dummy parameter $\delta_{1}=0$

$\mathrm{H}_{0}=\delta_{1}=0$

Hypothesis 2: This was to test for equal relative price or allocative efficiency in profit of rainforest and savannah zones respectively:

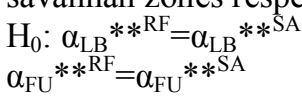

Hypothesis 3: This states that there is equal relative technical and price efficiency jointly between rainforest and savannah NTFP users.

$$
\begin{aligned}
& \mathrm{H}_{0}: \delta_{\mathrm{RF}} *=0 \\
& \alpha_{\mathrm{LB}} * * \mathrm{RF}=\alpha_{\mathrm{LB}} * \\
& \alpha_{\mathrm{FU}} * \mathrm{RF}^{*}=\alpha_{\mathrm{FU}} *
\end{aligned}
$$

Hypothesis 4: This states that rainforest users have absolute allocative or price efficiency, i.e. they maximize profits by equating the value of each factor's marginal product to the respective factor price.

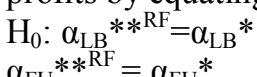

Hypothesis 5:This states that savannah NTFPs user have absolute allocative or price efficiency. 


$$
\begin{aligned}
& \mathrm{H}_{0}: \alpha_{\mathrm{LB}} * * \mathrm{SA}=\alpha_{\mathrm{LB}} * \\
& \alpha_{\mathrm{FU}} * \mathrm{SA}^{*}=\alpha_{\mathrm{FU}} *
\end{aligned}
$$

Hypothesis 6: This states that there is constant return to scale. This test was carried out with the restriction of profit maximization as well as constant returns to scale $\beta_{\mathrm{XT}}+\beta_{\mathrm{LD}}=1$

$$
\begin{aligned}
& \alpha_{\mathrm{LB}} * * \mathrm{RF}=\alpha_{\mathrm{LB}} * * \mathrm{SA} \\
& \alpha_{\mathrm{FU}} * * \mathrm{RF}=\alpha_{\mathrm{FU}} * * \mathrm{SA} \\
& \alpha_{\mathrm{LB}} * * \mathrm{RF}=\alpha_{\mathrm{LB}} * ; \beta_{\mathrm{XT}}+\mathrm{B}_{\mathrm{LD}}=1 \\
& \alpha_{\mathrm{FU}} * * \mathrm{RF}=\alpha_{\mathrm{FU}} *
\end{aligned}
$$

\subsection{Socio-economic analysis of NTFPs Users.}

\section{Results and discussion.}

Descriptive statistics was used to analyse the socio-economic characteristics of individuals involved in NTFPs activities (gathering, processing and marketing) the analysis consists of sex, age, level of education, household size, income level, etc.

Table 4.1 shows that the five (5) major NTFPs in the study area are food crops, fuelwood/charcoal, bushmeat e.g. grasscutter, fruits, e.g. wild mangoes, medicinal herbs and others. The table shows that 28 percent of the respondents are engaged in tuangya farming with the production of food crops like maize, cassava, yam and cowpea. This shows the importance of NTFPs to household food security. 25.3 percent are engaged in fuelwood/charcoal activities while 20.7 percent are engaged in Bush meat activities. 13.3 percent are engaged in gathering fruits like shear butter, wild mangoes etc while 10.7 are engaged in medicinal herbs while 2 percent are engaged in other activities like sponge, ropes, honey etc.

However, for ease of analysis only two major NTFPs - Flora (fuelwood and Fauna - Bushmeat) will be used in the normalized profit function analysis.

The results indicate that the male individuals that represent $71.3 \%$. This shows the dominance of women in NTFPs activities. (see table 4.1). The individuals whose age fall between 31-50 years constitute the major $(83.4 \%)$. The age group $>50 y$ rs with $8.7 \%$ follows this. On the whole, $91.4 \%$ fall into the economically active age group of $20-50$ years showing that majority of NTFPs individuals are in the physical active age. The result of the marital status shows that majority $(88 \%)$ of NTFPs individuals were married while minority of them $(10 \%)$ were single.

The individuals with no formal education constitute $31.3 \%$ while those with primary education represent $36.7 \%$. This sums up NTFPs individuals below secondary school level education to be $68 \%$. Those with secondary and tertiary education level occupy a small $32.0 \%$. Since education affects productivity of NTFPs individuals, this scenario of low literacy greatly impaired the adaptability of the inputs used and had a negative impact on the productivity of NTFPs individuals.

The distribution of household size indicates that the household size ranged from 1 to 12 with an average of 7 . Most of the NTFPs individuals (77.3\%) had a family size of 5-8 while $2 \%$ had a family size of 9-12 persons. This high family size encourages the substitution of family labour for hired labour which in turn reduces the cost of labour.

\begin{tabular}{|c|c|c|c|c|c|}
\hline $\mathbf{S} / \mathbf{N}$ & Variable & Category & Frequency & $\%$ & Cumulative \% \\
\hline 1. & Age & $\begin{array}{l}\leq 30 \\
31-50 \\
>50\end{array}$ & $\begin{array}{l}12 \\
125 \\
13 \\
\end{array}$ & $\begin{array}{l}8 \\
83.4 \\
8.7 \\
\end{array}$ & $\begin{array}{c}8 \\
91.4 \\
100 \\
\end{array}$ \\
\hline 2 & Sex & $\begin{array}{l}\text { Male } \\
\text { Female }\end{array}$ & $\begin{array}{l}43 \\
107 \\
\end{array}$ & $\begin{array}{l}28.7 \\
71.3 \\
\end{array}$ & $\begin{array}{l}28.7 \\
100 \\
\end{array}$ \\
\hline 3 & Marital Status & $\begin{array}{l}\text { Single } \\
\text { Married } \\
\text { (Others Widowed } \\
\text { Divorced, separated) }\end{array}$ & $\begin{array}{l}15 \\
132 \\
3\end{array}$ & $\begin{array}{l}10 \\
88 \\
2\end{array}$ & $\begin{array}{l}10 \\
98 \\
100\end{array}$ \\
\hline 4 & Educational Status & $\begin{array}{l}\text { No formal education } \\
\text { Primary } \\
\text { Secondary/Tertiary }\end{array}$ & $\begin{array}{l}47 \\
55 \\
48\end{array}$ & $\begin{array}{l}31.3 \\
36.7 \\
32.0\end{array}$ & $\begin{array}{l}31.3 \\
68.0 \\
100\end{array}$ \\
\hline 5 & NTFP experience & $\begin{array}{l}<10 \\
10-20 \\
21-30 \\
31-40 \\
>40\end{array}$ & $\begin{array}{l}106 \\
31 \\
5 \\
3 \\
5 \\
\end{array}$ & $\begin{array}{l}70.7 \\
20.7 \\
3.3 \\
2.0 \\
3.3 \\
\end{array}$ & $\begin{array}{l}70.7 \\
91.4 \\
94.7 \\
96.7 \\
100 \\
\end{array}$ \\
\hline
\end{tabular}

The amount of income generated by individual's involved NTFPs activity per month is high. $61.3 \%$ earn above N20,000 per month. This supports the fact that NTFPs trade is profitable which may be due to low expenditure incurred in the trade. Hence, government should encourage NTFPs activities to alleviate poverty by increasing the income of the rural dwellers.

Table 4.1 Distribution of Socio-economic Characteristics of Farmers 
Economics of non-timber forest products (NTFPS) in Oyo-state, Nigeria.

\begin{tabular}{|c|c|c|c|c|c|}
\hline 6 & Family Size & $\begin{array}{l}\text { No response } \\
1-4 \\
5-8 \\
9-12\end{array}$ & $\begin{array}{l}14 \\
17 \\
116 \\
3\end{array}$ & $\begin{array}{l}9.3 \\
11.3 \\
77.3 \\
2.0\end{array}$ & $\begin{array}{l}9.3 \\
20.6 \\
97.9 \\
100\end{array}$ \\
\hline 7 & Monthly Income & $\begin{array}{l}<5,000 \\
5,000-9,999 \\
10,000-14,999 \\
15,000-19,999 \\
>20,000\end{array}$ & $\begin{array}{l}2 \\
6 \\
26 \\
24 \\
92 \\
\end{array}$ & \begin{tabular}{l|}
1.3 \\
4.0 \\
17.3 \\
16.0 \\
61.3 \\
\end{tabular} & $\begin{array}{l}1.3 \\
5.3 \\
22.6 \\
38.6 \\
100\end{array}$ \\
\hline 8 & Religion & $\begin{array}{l}\text { Ibadan } \\
\text { Christianity } \\
\text { Traditional Religion }\end{array}$ & $\begin{array}{l}62 \\
79 \\
9 \\
\end{array}$ & $\begin{array}{l}41.3 \\
52.7 \\
6.0 \\
\end{array}$ & $\begin{array}{l}41.3 \\
94 \\
100 \\
\end{array}$ \\
\hline 9 & Proximity & $\begin{array}{l}1-5 \\
6-10 \\
11-15 \\
\end{array}$ & $\begin{array}{l}129 \\
20 \\
1 \\
\end{array}$ & $\begin{array}{l}86.0 \\
13.3 \\
0.7 \\
\end{array}$ & $\begin{array}{l}86.0 \\
99.3 \\
100 \\
\end{array}$ \\
\hline 10 & Source of NTFPs & $\begin{array}{l}\text { Free Areas (FA) } \\
\text { Forest Reserves (FR) } \\
\text { Both (FA \& FR) }\end{array}$ & $\begin{array}{l}11 \\
98 \\
41 \\
\end{array}$ & $\begin{array}{l}7.3 \\
65.3 \\
27.3 \\
\end{array}$ & $\begin{array}{l}7.3 \\
72.6 \\
100 \\
\end{array}$ \\
\hline 11 & Ecological Zone & $\begin{array}{l}\text { Shaki } \\
\text { Ibadan/Ibarapa }\end{array}$ & $\begin{array}{l}75 \\
75\end{array}$ & $\begin{array}{l}50 \\
50\end{array}$ & $\begin{array}{l}50 \\
100\end{array}$ \\
\hline 12 & Seasonality & $\begin{array}{l}\text { Rainy } \\
\text { Dry } \\
\text { Both }\end{array}$ & $\begin{array}{l}9 \\
55 \\
86\end{array}$ & $\begin{array}{l}6.0 \\
36.7 \\
57.3 \\
\end{array}$ & $\begin{array}{l}6.0 \\
42.7 \\
100\end{array}$ \\
\hline 13 & $\begin{array}{l}\text { Monthly } \\
\text { Expenditure }\end{array}$ & $\begin{array}{l}<1000 \\
1000-4,999 \\
5,000-14,999 \\
>15,000\end{array}$ & $\begin{array}{l}4 \\
49 \\
67 \\
14 \\
16\end{array}$ & $\begin{array}{l}2.7 \\
32.7 \\
44.7 \\
9.3 \\
10.7\end{array}$ & $\begin{array}{l}2.7 \\
35.4 \\
80.1 \\
89.4 \\
100\end{array}$ \\
\hline 14 & Major NTFPs & $\begin{array}{l}\text { Food } \\
\text { Fuelwood/Charcoal } \\
\text { Bushmeat } \\
\text { Fruits } \\
\text { Medicinal herbs } \\
\text { Others e.g Sponge } \\
\end{array}$ & $\begin{array}{l}42 \\
38 \\
31 \\
20 \\
16 \\
3 \\
\end{array}$ & $\begin{array}{l}28.0 \\
25.3 \\
20.7 \\
13.3 \\
10.7 \\
2.0 \\
\end{array}$ & $\begin{array}{l}28.0 \\
53.3 \\
74.0 \\
87.3 \\
98 \\
100 \\
\end{array}$ \\
\hline
\end{tabular}

From the table, it can be observed that $86.0 \%$ of the individual involved in NTFPs activities got their products at a distance of between $1-5 \mathrm{~km}$. This helps to reduce transportation cost and conserve their energy thereby increasing their efficiency and productivity. Also from the table, we can see that majority of the people involved NTFPs activities gather them from forest reserves $(65.3 \%)$ while $71.3 \%$ gather theirs from free areas. The implication is that forest reserves are very significant to the livelihood of the rural dwellers and urban dwellers. Government should encourage the effective management of forest resources for sustainability.

\subsection{Regression results.}

The regression analysis was carried out to determine the impact of certain socio-economic variables like age, sex, marital status, educational level on the income level of people involved in NTFPs activities. Three forms of equations were estimated. These are linear, semi-log and double-log. According to Olayemi and Olaniyi (1981), the choice of appropriate functional form might be approached in many ways; first the choice may be based on a priori expectations, which is in turn guided by economic theory. In this regard, the appropriate functional form may be determined "experimentally" by fitting various functions and selecting the best on the basis of economic and statistical criteria. According to Onyeweaku (1978), other criteria for choosing the most appropriate functional form include (1) computational simplicity, theoretical justification, finding from previous studies and the nature of the commodity concerned. Others include the coefficient of multiple correlations $\mathrm{R}^{2}$, or the adjusted $\mathrm{R}^{2}$, standard errors of regression estimates, t-ratios and the reasonableness of the estimated coefficients with respect to signs and magnitude.

On the basis of the statistical and economic criteria, i.e signs of regression coefficients, magnitude of coefficient determination $\left(\mathrm{R}^{2}\right)$ and standard error, the double-logarithm equation was chosen as the lead equation for NTFPs individuals as shown in Table 4.2. The implicit double-log function is given as:

$\log \mathrm{Y}=34.061+1.841 \log \mathrm{X}_{1}-1.369 \log \mathrm{X}_{2}+2.760 \log \mathrm{X}_{3}+4.282 \log \mathrm{X}_{4}$
$(0.1211)$
$(0.0025)^{*}$
$(0.01182)$
$(3.7330 \mathrm{E}-06)^{* * *}(2.7491 \mathrm{E}-06)^{* * *}$

$+0.169 \log \mathrm{X}_{5}-0.177 \log \mathrm{X}_{6}-5.375 \log \mathrm{X}_{7}-0.110 \log \mathrm{X}_{8}+1.404 \log \mathrm{X}_{9}$
$(0.02028)(0.0290)$
$(0.02078)^{* * *}$
$(0.0366)$
$(0.0524)$
$-0.889 \log$
$(0.0082)$
$(0.0018)$
$2.052 \log \mathrm{X}$
$(0.0255)^{* *}$
$(0.0338)^{* * *}$
$(0.0113)$ 
$+1.758 \log \mathrm{X}_{15}+2.655 \log \mathrm{X}_{16}-1.597 \log \mathrm{X}_{17}$

$(1.4823 \mathrm{E}-05) \quad(1.0594 \mathrm{E}-06)^{*} \quad(0.0294)$

$\mathrm{R}^{2}=0.44908 ; \mathrm{R}^{2}=0.37813$; multiple $\mathrm{R}^{-2}=0.67013$.

$\mathrm{F}_{\mathrm{cal}}=6.32937$

Key :Figures in parenthesis represent the standard error at $\mathrm{t}$ - value $(1 \%)=2.33^{*}$

$*=$ Variables significant at $10 \%$;

$* *=$ Variables significant at $5 \%$;

$* * *=$ Variables significant at $1 \%$

Table 4.2: Regression Analysis for Non-Forest Products Users

\begin{tabular}{|c|c|c|c|c|c|c|c|c|c|c|c|}
\hline $\begin{array}{l}\text { Equ } \\
\text { ation }\end{array}$ & $\begin{array}{l}\text { bo } \\
\text { Constan } \\
t\end{array}$ & $\mathrm{~b}_{1}$ Age & $\begin{array}{l}\mathrm{b}_{2} \\
\text { House } \\
\text { hold } \\
\text { Size }\end{array}$ & $\begin{array}{l}\text { Other } \\
\text { income } \\
\text { sources } \\
b_{3}\end{array}$ & $\begin{array}{l}\text { Expendit } \\
\text { ure } \\
\mathrm{B}_{4}\end{array}$ & $\begin{array}{l}\text { Educ } \\
\text { ation } \\
\mathrm{b}_{5}\end{array}$ & $\begin{array}{l}\text { NTF } \\
\text { Ps } \\
\text { Sour } \\
\text { ces } \\
b_{6}\end{array}$ & $\begin{array}{l}\text { Eco- } \\
\text { Zone } b_{7}\end{array}$ & $\begin{array}{l}\text { Sex } \\
b_{8}\end{array}$ & $\begin{array}{l}\text { Marit } \\
\text { al } \\
\text { status } \\
\text { b }_{9}\end{array}$ & $\begin{array}{l}\text { Proxi } \\
\text { mity } \\
\mathrm{b}_{10}\end{array}$ \\
\hline $\begin{array}{l}\text { Line } \\
\text { ar }\end{array}$ & $\begin{array}{l}2.355 \\
(6791.9 \\
6)^{* *}\end{array}$ & $\begin{array}{l}0.883 \\
(142.9 \\
20)\end{array}$ & $\begin{array}{l}-0.385 \\
(661.7 \\
7)\end{array}$ & $\begin{array}{l}2.340 \\
(0.208)^{*} \\
*\end{array}$ & $\begin{array}{l}4.304 \\
(0.154)^{* *}\end{array}$ & $\begin{array}{l}0.093 \\
(113 \\
4.94)\end{array}$ & $\begin{array}{l}- \\
0.452 \\
(162 \\
3.34) \\
\end{array}$ & $\begin{array}{l}-5.468 \\
(1162.9 \\
5)^{* * *}\end{array}$ & $\begin{array}{l}0.116 \\
(204 \\
8.54)\end{array}$ & $\begin{array}{l}1.739 \\
(2937 . \\
27)^{*}\end{array}$ & $\begin{array}{l}- \\
0.363 \\
(461 . \\
62\end{array}$ \\
\hline $\begin{array}{l}\text { Dou } \\
\text { ble- } \\
\text { log }\end{array}$ & $\begin{array}{l}34.061 \\
(0.1211 \\
)\end{array}$ & $\begin{array}{l}1.841 \\
(0.002 \\
5)^{*}\end{array}$ & $\begin{array}{l}-1.369 \\
(0.011 \\
82)\end{array}$ & $\begin{array}{l}2.760 \\
(3.7330 \\
\text { E- } 06)^{* *}\end{array}$ & $\begin{array}{l}4.282 \\
(2.7491 \mathrm{E} \\
-06)^{* * *}\end{array}$ & $\begin{array}{l}0.169 \\
(0.02 \\
028)\end{array}$ & $\begin{array}{l}- \\
0.177 \\
(0.02 \\
90) \\
\end{array}$ & $\begin{array}{l}-5.375 \\
(0.0207 \\
8)^{* * *}\end{array}$ & $\begin{array}{l}- \\
0.110 \\
(0.03 \\
66)\end{array}$ & $\begin{array}{l}1.404 \\
(0.052 \\
4)\end{array}$ & $\begin{array}{l}- \\
0.889 \\
(0.00 \\
82)\end{array}$ \\
\hline $\begin{array}{l}\text { Sem } \\
\text { i-log }\end{array}$ & $\begin{array}{c}-2.515 \\
(22202 . \\
02)^{* *}\end{array}$ & $\begin{array}{l}1.672 \\
(13389 \\
.67)^{*}\end{array}$ & $\begin{array}{l}-0.602 \\
(5276 . \\
32)\end{array}$ & $\begin{array}{l}1.605 \\
(495.40)\end{array}$ & $\begin{array}{l}4.163 \\
(2890.72)\end{array}$ & $\begin{array}{l}0.864 \\
(702 \\
9.26)\end{array}$ & $\begin{array}{l}- \\
0.049 \\
(707 \\
0.63)\end{array}$ & $\begin{array}{l}-4.522 \\
(8443.1 \\
8)^{* * *}-\end{array}$ & 0.046 & $\begin{array}{l}0.046 \\
(2110 \\
0.62)\end{array}$ & $\begin{array}{l}0.188 \\
(473 \\
9.91)\end{array}$ \\
\hline
\end{tabular}

\begin{tabular}{|c|c|c|c|c|c|c|c|c|c|c|c|}
\hline $\begin{array}{l}\text { Equati } \\
\text { on }\end{array}$ & $\begin{array}{l}\text { Experie } \\
\text { nce } b_{11}\end{array}$ & $\begin{array}{c}\text { Religio } \\
\mathrm{n} \mathrm{b}_{12}\end{array}$ & $\begin{array}{l}\text { Major } \\
\text { occupat } \\
\text { ion } \\
b_{13}\end{array}$ & $\begin{array}{l}\text { Major } \\
\text { NTFPs } \\
\mathrm{b}_{14}\end{array}$ & $\begin{array}{l}\text { Qty of } \\
\text { major } \\
\text { NTFPs } \\
\mathrm{b}_{15}\end{array}$ & $\begin{array}{l}\text { Price } \\
\text { of } \\
\text { major } \\
\text { NTFPs } \\
b_{16}\end{array}$ & $\begin{array}{l}\text { Seasona } \\
\text { lity } \mathrm{b}_{17}\end{array}$ & $\mathrm{R}^{2}$ & $\mathbf{R}^{-2}$ & F-cal & S.E \\
\hline Linear & $\begin{array}{l}1.042 \\
(100.18 \\
)\end{array}$ & $\begin{array}{l}-1.673 \\
(1427 \\
28)^{*}\end{array}$ & $\begin{array}{l}-1.501 \\
(1982.1 \\
6)\end{array}$ & $\begin{array}{l}0.816 \\
(636.2 \\
8) \\
\end{array}$ & $\begin{array}{l}1.642 \\
(0.829)\end{array}$ & $\begin{array}{l}2.859 \\
(0.059) \\
* * *\end{array}$ & $\begin{array}{l}-1.926 \\
1643.19 \\
)\end{array}$ & $\begin{array}{l}0.4 \\
185\end{array}$ & 0.343 & 5.589 & $\begin{array}{l}9561 . \\
80\end{array}$ \\
\hline $\begin{array}{l}\text { Doubl } \\
\text { e-log }\end{array}$ & $\begin{array}{l}1.272 \\
(0.0018 \\
)\end{array}$ & $\begin{array}{l}-2.052 \\
(0.025 \\
5)^{* *}\end{array}$ & $\begin{array}{l}-2.822 \\
(0.0338 \\
)^{* * *}\end{array}$ & $\begin{array}{l}1.002 \\
(0.011 \\
3)\end{array}$ & $\begin{array}{l}1.758 \\
(1.4823 \\
\text { E-05)* }\end{array}$ & $\begin{array}{l}2.655 \\
(1.059 \\
4 \mathrm{E}- \\
06)^{*}\end{array}$ & $\begin{array}{l}-1.597 \\
(0.0294 \\
)^{*}\end{array}$ & $\begin{array}{l}0.4 \\
49\end{array}$ & 0.378 & 6.329 & 0.171 \\
\hline $\begin{array}{l}\text { Semi- } \\
\log \end{array}$ & $\begin{array}{c}1.695 \\
(2476.4 \\
3)^{*}\end{array}$ & $\begin{array}{l}-0.625 \\
(12692 \\
.51)\end{array}$ & $\begin{array}{l}-1.610 \\
(13755 . \\
88)\end{array}$ & $\begin{array}{l}0.473 \\
(3950 . \\
96)\end{array}$ & $\begin{array}{l}1.192 \\
(0.912)\end{array}$ & $\begin{array}{l}2.842 \\
(0.061)\end{array}$ & $\begin{array}{l}-2.102 \\
(1592.1 \\
2)^{* *}\end{array}$ & $\begin{array}{l}0.3 \\
83\end{array}$ & 0.309 & 5.171 & $\begin{array}{l}9809 . \\
53\end{array}$ \\
\hline
\end{tabular}

* Significant at $10 \%$ level

** Significant at $5 \%$ level

$* * *$ Significant at $1 \%$ level

Values in parentheses are standard errors.

The coefficient of multiple determinations $\left(\mathrm{R}^{2}\right)$ was found to be 0.44908 . This implies that 44.9 percent of the total variation in the income of non-timber product user is explained by the significant variables age, other sources of income, expenditure in naira, ecological zone, religion, major occupation, quantity of nontimber forest products. The remaining 55.1 percent will be attributed to error term, which arises as a result of discrepancies in the values obtained, or some other variables not included in the model. The constant term and the regression coefficients b1, (age), b3 (other sources of income), b4 (expenditure), b7 (ecological zone), b12 (religion), b13 (major occupation), b15 (quantity of NTFPs marketed), b16 (price of major NTFPs) are statistically significant at 1 percent level. Also from the regression equation, the coefficient having positive signs show that the variables ( age, other sources of income quantities of major NTFPs, price of major NTFPs have direct relationship with gross income. Thus an increase in other sources of income will give a corresponding increase in income of NTFPs uses. Also the higher the price of the NTFPs in the market, the higher the income generated by the uses. Also the higher the quantities harvested, the higher the profit or income realized. Also age is directly proportional to income. Thus an increase in the age of the NTFPs user, the higher the income realized. 
Economics of non-timber forest products (NTFPS) in Oyo-state, Nigeria.

\subsection{Gross margin analysis.}

The gross margin of an enterprise is the difference between the total value of production and the variable costs of production. The gross margin analysis was used to determine the profitability of NTFPs in the study areaas shown in .

Table 4.3.1:Costs and Returns for NTFPs in the Study Area (Gross Margin Analysis for the Major NTFPs in the Study Area)

\begin{tabular}{|c|c|c|c|c|c|c|c|c|}
\hline $\begin{array}{l}\text { NTFPs } \\
\text { Costs/Return(N) }\end{array}$ & Wildlife & Fuelwood & Food & Fruits & $\begin{array}{l}\text { Med. } \\
\text { Herbs }\end{array}$ & Others & Total & Percentage \\
\hline Total Revenue (TR) & $763,537.50$ & 432,430 & 411,540 & 386,550 & $175,649.99$ & $178,509.08$ & $2,348,267.57$ & 80 \\
\hline Cost of gathering & 138,432 & $253,772.80$ & 243,296 & 62,156 & 35,704 & 85,936 & $819,296.80$ & 11 \\
\hline Cost of Processing & $19,034.00$ & $34,893.76$ & $33,453.20$ & $\begin{array}{l}8,546.4 \\
5\end{array}$ & $4,909.30$ & $11,816.20$ & $112,652.91$ & 5 \\
\hline $\begin{array}{l}\text { Cost of } \\
\text { Marketing/Transpor- } \\
\text { tation }\end{array}$ & 8,652 & $15,860.80$ & 15,206 & $\begin{array}{l}3,884.7 \\
5\end{array}$ & $2,231.50$ & 5,371 & 51,371 & 4 \\
\hline Miscellaneous & $6,921.60$ & $12,688.64$ & $12,164.80$ & $\begin{array}{l}3,107.8 \\
0\end{array}$ & $1,785.20$ & $4,296.80$ & $40,964.84$ & \\
\hline $\begin{array}{l}\text { Total Variable } \\
\text { Cost(TVC) }\end{array}$ & 173,040 & 317,216 & 304,120 & 77,695 & 44,630 & 107,420 & 1024,121 & \\
\hline GM (Gross Margin) & $590,497.50$ & 115,214 & 107,420 & 308,855 & $131,019.99$ & $71,149.08$ & $1,324,155.57$ & \\
\hline
\end{tabular}

Table 4.3.2: $\quad$ Monthly Quantities and Costs for the NTFPs in the Study Area

\begin{tabular}{|l|l|l|l|l|}
\hline S/N & NTFPs & QTY & Cost (N) & Percentage \\
\hline 1 & Wildlife & $2,776.50$ & 173,040 & 17 \\
2 & Fuel wood & $64,864.50$ & 317,216 & 31 \\
3 & Food & 16,245 & 304,120 & 30 \\
4 & Fruits & 7,731 & 77,695 & 8 \\
5 & Medical herbs & $5,269.50$ & 44,630 & 4 \\
6 & Others & $2,986.75$ & 107,420 & 10 \\
\hline & Total & $99,873.25$ & $1,024,121$ & 100 \\
\hline
\end{tabular}

Source: Field Survey

Table 4.3.2 shows that the highest expenditure (cost) is incurred on food crops planted in the forest reserve (Taungya farming) while the least cost is expended in gathering medical herbs.

Table 4.3.3: Income According to Sources of NTFPs

\begin{tabular}{|l|l|l|l|l|l|l|l|l|}
\hline $\begin{array}{l}\text { NTFPs } \\
\text { Source }\end{array}$ & Fuelwood & Wildlife & Food & Fruits & $\begin{array}{l}\text { Med. } \\
\text { Herbs }\end{array}$ & Others & Total & $\begin{array}{l}\text { Percentag } \\
\text { e }\end{array}$ \\
\hline Forest & 282520.9 & 498844.5 & 266872.8 & 252546 & 114757.9 & 116665.5 & 1537207.35 & 65.33 \\
Reserves & 3 & 0 & 0 & 28374 & 9 & 1 & 9 & 7.33 \\
Free-Areas & 31711.53 & 55992.75 & 30179.60 & 105657 & 12880.99 & 13095.06 & 13095.06 & 27.33 \\
Both & 118197.5 & 208700.2 & 112487.6 & & 48010.99 & 48808.88 & 48808.88 & \\
& 0 & 5 & 0 & & & & & \\
\hline Total & 432430 & 763537.5 & 411540 & 386550 & 175649.9 & 178569.0 & 2348276.57 & 100 \\
& & 0 & & & 9 & 8 & & \\
\hline
\end{tabular}

Table 4.3.3 shows that the highest income generated from forest resources for all the major non-timber forest products. This means that efforts should be made by the government (Federal and State) to reactivate the forest reserves so as to serve as sources of income/employment, food etc to forest dwellers

Table 4.3.4 shows that income is realized most in Guinea Savannah which comprises both the rainforest and savannah respectively. 50percent of the total income generated from the forestry ecological zone is realized from this zone. The least income is realized from rainforest.

Table 4.3.5: shows that the most hunted wildlife is grass cutter which also generated the highest level of income of $\mathrm{N} 425,136.25$. This is as a result of its high protein potential.

Table 4.3.4: Income of NTFPs According to Ecological Zone

\begin{tabular}{|c|c|c|c|c|c|c|c|c|}
\hline $\begin{array}{l}\text { Eco. } \\
\text { Zone }\end{array}$ & $\begin{array}{l}\text { Fuel } \\
\text { Wood }\end{array}$ & $\begin{array}{l}\text { Wild } \\
\text { Life }\end{array}$ & Food & Fruit & $\begin{array}{l}\text { Med. } \\
\text { Herbs }\end{array}$ & Others & Total & $\begin{array}{l}\text { percentag } \\
\text { e }\end{array}$ \\
\hline Rainfores & $103,783.2$ & 183,249 & $98,769.6$ & 92,772 & $42,155.99$ & $42,856.57$ & $56,3586.34$ & 24 \\
\hline $\mathrm{t}$ & 0 & $381,768.7$ & 0 & 19,327 & $87,824.99$ & $89,284.54$ & $117,4138.28$ & 50 \\
\hline GS & 216,215 & 5 & 20,5770 & 5 & $45,668.99$ & $46,427.96$ & & 26 \\
\hline DS & $\begin{array}{l}112,431.8 \\
0\end{array}$ & $98,519.75$ & $\begin{array}{l}10,700.4 \\
0\end{array}$ & $\begin{array}{l}100,50 \\
3\end{array}$ & & & $610,551.91$ & \\
\hline Total & 432,430 & $763,537.5$ & 411,540 & 386,55 & $175,649.9$ & $178,596.0$ & $234,8276.57$ & 100 \\
\hline
\end{tabular}


Economics of non-timber forest products (NTFPS) in Oyo-state, Nigeria.

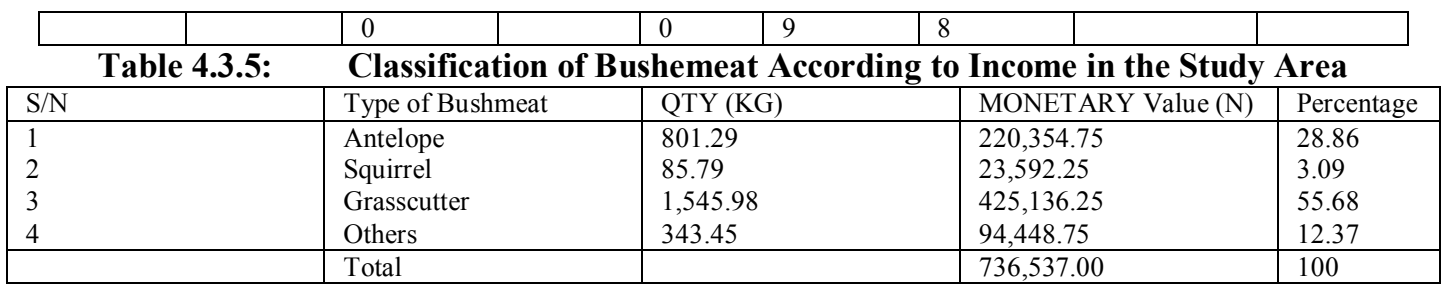

Gross margin $=$ Gross Income - Total Variable Cost $(\mathrm{N})$

$\mathrm{GM}=\mathrm{GI}-\mathrm{TVC}$

The total variable cost was calculated to be $=\mathrm{N} 1,024,121$

Total revenue (Gross income) $=$ N2,348,267.57

Total variable cost $/$ seller $=\mathrm{N} 6,827.47$

Total revenue per seller $=\mathrm{N} 15,655.11$

Gross margin per seller $=\mathrm{N} 15,655.11-\mathrm{N} 6,827.47=\mathrm{N} 8,827.64$

The above analysis shows the NTFPs sellers earned an average of N8,827.64 per month as gross margin which indicates that NTFPs business is a profitable business in the study area which can be operated with a small investment capital which may be important reason why a lot of people are engaged in it.

\section{4 . Gini coefficient}

From table 4.4, gini coefficient is calculated with the formula

$\mathrm{G}=1-\Sigma\left(\mathrm{X}_{\mathrm{i}+1}-\mathrm{X}_{\mathrm{i}}\right)\left(\mathrm{Y}_{\mathrm{i}}-\mathrm{Y}_{\mathrm{i}+1}\right)$

Where $X_{i}=$ cumulative percentage of respondents

$Y_{i}=$ cumulative percentage of income

Table 4.4:Computation of gini coefficient for NTFPs users in Oyo State

\begin{tabular}{|c|c|c|c|c|c|}
\hline Income group & $\mathrm{X}_{\mathrm{i}}$ & $\mathrm{Y}_{\mathrm{i}}$ & $\mathrm{X}_{\mathrm{i}+1}-\mathrm{X}_{\mathrm{i}}$ & $\mathrm{Y}_{\mathrm{i}+1}+\mathrm{Y}_{\mathrm{i}}$ & $\begin{array}{c}\left(\mathrm{X}_{\mathrm{i}+1}-\mathrm{X}_{\mathrm{i}}\right) \\
\left.\mathrm{Y}_{\mathrm{i}+1}+\mathrm{Y}_{\mathrm{i}}\right) \\
\end{array}$ \\
\hline $\begin{array}{l}<5000 \\
5000-9,999 \\
10,000-14,999 \\
15,000-19,999 \\
>20,000\end{array}$ & $\begin{array}{l}0.11 \\
0.26 \\
0.16 \\
0.12 \\
0.35\end{array}$ & $\begin{array}{l}.0 .0136 \\
0.1306 \\
0.2427 \\
0.3682 \\
0.0035\end{array}$ & $\begin{array}{l}0.15 \\
-0.1 \\
-0.04 \\
0.23\end{array}$ & $\begin{array}{l}0.01442 \\
0.3733 \\
0.6109 \\
0.3717\end{array}$ & $\begin{array}{l}0.02163 \\
-0.03733 \\
-0.024436 \\
0.085491\end{array}$ \\
\hline Total & & & & & 0.045355 \\
\hline
\end{tabular}

Source: Survey Data 2002

Gini Coefficient $(G)=1-\Sigma\left(X_{i+1}-X_{i}\right)\left(Y_{i}-Y_{i+1}\right)$

$\mathrm{G}=1-0.45355$

$\mathrm{G}=0.954645$

\subsubsection{Normalized profit function result (fuel wood)}

The results of the estimated equation are presented in Table 4.5.1. All the coefficients have the expected theoretical signs. As is theoretically consistent, the coefficients of the prices of labour and fuel are negatively signed as expected. Capital and land are highly significant in the profit function (see table 4.5.1. and 4.5.2).

From the result of the normalized profit function for fuelwood, the ordinary least square regression (OLS) estimate and the factor share equation are given in column 3. The $\mathrm{R}^{2}$ value showed an explanation of 62 percent of the variation in the profit level by significant factors of production while the F-value was highly significant at 1 percent probability level. Since the costs of the variable inputs was used, they bear a negative relationship with the value of profit, hence, the negative signs in these coefficients. They are however all significant factors in NTFPs production. In the fourth column, the coefficient estimated with SURE without restriction are presented. This was done because of the ability of this method to jointly estimate the factor share equations with the normal profit function coefficients. The results obtained showed similarities with the result given in column 3. The coefficient bore the expected signs and they are all significant at 1 percent level. Other columns in the table showed the restrictions imposed in order to test for the hypothesis earlier state. The economic implications of the results are that the cost of production is highly significant in determining the level of farmers profit. Therefore every effort to reduce these cost in the production process will improve farmers profit status. Expansion of land area where NTFPs are collected will also increase farmers profit level. The increased use of farm implements also will expand production hence the profit level of farmers. 
Economics of non-timber forest products (NTFPs) in Oyo-state, Nigeria.

Table 4.5.1: Joint Estimation of the Normalized Profit function and Factor Share Equations for Variable Inputs of Non-timber forest products farmers (Fuelwood) Oyo State (n=40)

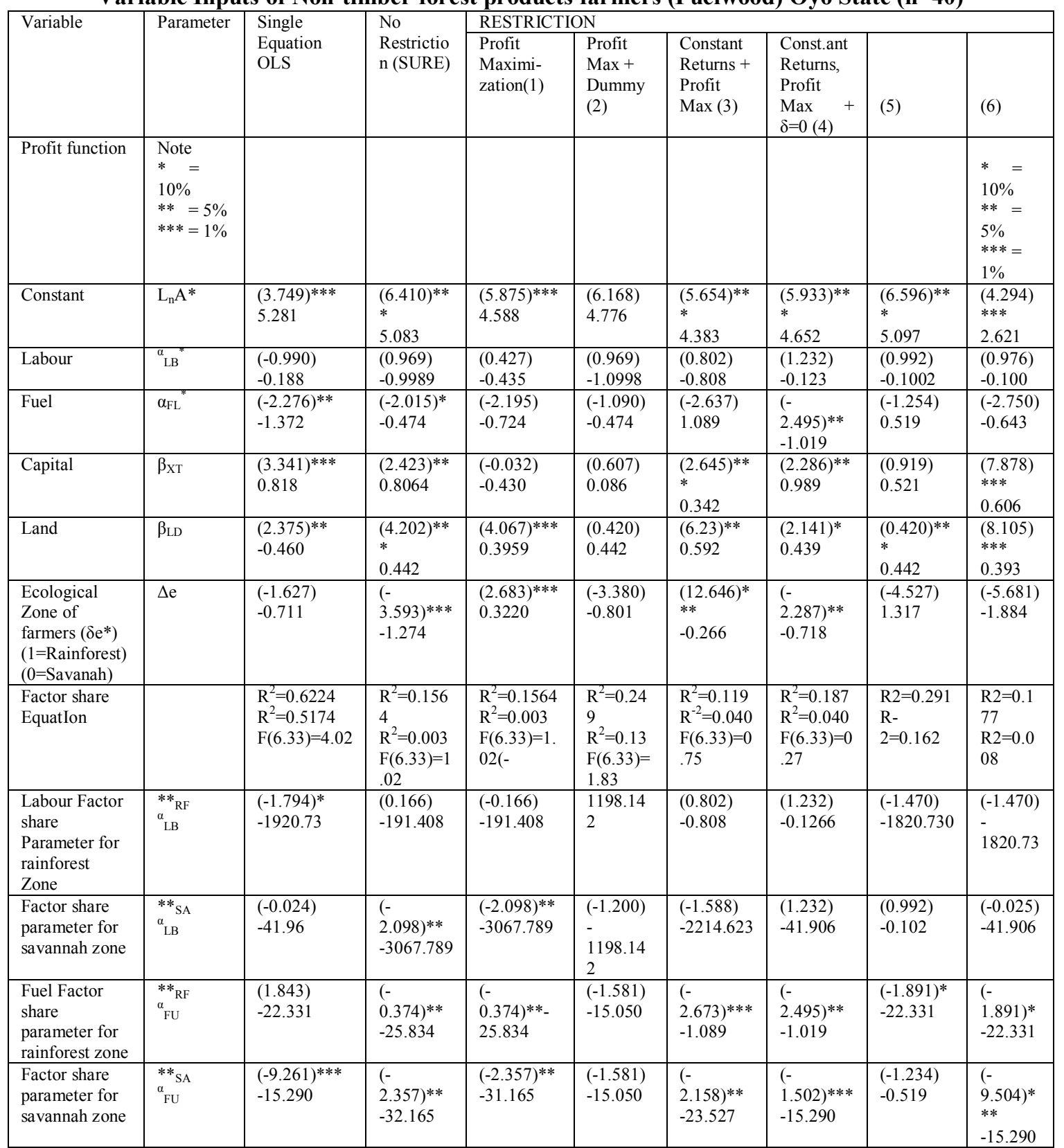

Table 4.5.2: Statistical tests of Hypothesis on differences in efficiency between NTFPs farmers in the rain forest zone and Savannah zone respectively (Fuelwood)

\begin{tabular}{|c|c|c|c|c|c|}
\hline Hypothesis & Tested & $\begin{array}{l}\text { Computed } \\
\mathrm{X}^{2}\end{array}$ & $\begin{array}{l}\text { Critical } \\
\mathrm{X}^{2}\end{array}$ & P-Value & Interpretation \\
\hline Hypothesis 1 & $\delta_{\mathrm{RF}}=\mathrm{O}$ & 12.909 & 3.841 & 0.0003 & $\begin{array}{l}\text { Since computed } X^{2}>\text { critical } X^{2} 0.05 \text {, this test } \\
\text { for economic efficiency implies that the } \\
\text { economic efficiency (technical and price } \\
\text { efficiency or allocative efficiency of } \\
\text { individuals involved in NTFPs in the rainforest } \\
\text { and savannah are not equal. The null } \\
\text { hypothesis is rejected. }\end{array}$ \\
\hline Hypothesis 2 & $\begin{array}{l}* *_{\mathrm{RF}} \begin{array}{c}* * *_{\mathrm{SA}} \\
= \\
\alpha_{\mathrm{LB}} * *_{\mathrm{SA}}\end{array} \\
\alpha_{\mathrm{LB} * *}={ }_{\mathrm{RF}}=\alpha_{\mathrm{FU}} \\
\alpha_{\mathrm{FU}}\end{array}$ & 4.56 & 5.991 & 0.1023 & $\begin{array}{l}\text { Since computed } \mathrm{X}^{2}<\text { critical } \mathrm{X}^{2}, 0.05 \text {, this test } \\
\text { implies that there is equal price or allocative } \\
\text { efficiency between individuals involved in } \\
\text { NTFPs activities in rainforest zone and } \\
\text { savannah zone respectively, i.e they equate the } \\
\text { value of marginal product of labour to wage } \\
\text { rate and the value of marginal product of fuel }\end{array}$ \\
\hline
\end{tabular}




\begin{tabular}{|c|c|c|c|c|c|}
\hline & & & & & $\begin{array}{l}\text { to fuel price to the same degree. Ho is } \\
\text { accepted. }\end{array}$ \\
\hline Hypothesis 3 & $\begin{array}{l}\delta_{\mathrm{RF}}^{* * *}{ }^{\mathrm{O}}{ }_{\mathrm{RF}=} \alpha_{\mathrm{LB}}{ }^{*} * \\
\alpha_{\mathrm{LB} * \mathrm{RF}}=\alpha_{\mathrm{FU}} \\
\alpha_{\mathrm{FU}}\end{array}$ & 20.55 & 7.815 & 0.0001 & $\begin{array}{l}\text { Since computed } X^{2}>\text { critical } X^{2} \text { at } 0.05 \text {, this } \\
\text { test implies that there is non-equality of relative } \\
\text { technical and price efficiency jointly between } \\
\text { rainforest and savannah users of NTFPs.Ho is } \\
\text { rejected. }\end{array}$ \\
\hline Hypothesis 4 & $\begin{array}{l}{ }^{* * \mathrm{RF}=\alpha \mathrm{LB}}{ }^{*} \\
* \\
\alpha \mathrm{LB}^{* *}=\mathrm{RF}=\alpha_{\mathrm{FU}} \\
\alpha_{\mathrm{FU}}\end{array}$ & 15.32 & 5.991 & 0.0005 & $\begin{array}{l}\text { Since computed } \mathrm{X}^{2}>\text { critical } \mathrm{X}^{2} \text { at } 0.05 \text {, this } \\
\text { test implies that those involved in NTFPs } \\
\text { activities in the rainforest zone do not have } \\
\text { absolute allocative or price efficiency.Ho is } \\
\text { rejected. }\end{array}$ \\
\hline Hypothesis 5 & $\begin{array}{l}*_{\mathrm{SA}=\alpha \mathrm{LB}} * \\
=\alpha \mathrm{LB} * * \mathrm{SA}=\alpha_{\mathrm{FU}} \\
\alpha_{\mathrm{FU}}\end{array}$ & 0.1546 & 5.991 & 0.9256 & $\begin{array}{l}\text { Since computed } \mathrm{X}^{2}<\text { critical } \mathrm{X}^{2} \text { at } 0.05 \text {, this } \\
\text { test implies that individuals involved in NTFPs } \\
\text { activities in the savannah zone have absolute } \\
\text { allocative efficiency i.e, they equate the value } \\
\text { of marginal product of variable inputs to the } \\
\text { opportunity cost.Ho is accepted. }\end{array}$ \\
\hline Hypothesis 6 & $\begin{array}{l}* *_{\mathrm{RF}}=\alpha_{\mathrm{LB}} * * \mathrm{SA} \\
\alpha_{\mathrm{LB}}^{* *} \mathrm{RF}=\alpha_{\mathrm{FU}} * \\
\alpha_{\mathrm{FU}} * * \mathrm{RF}=\alpha_{\mathrm{LB}} \\
\alpha_{\mathrm{LB}} * * \mathrm{RF} \\
\alpha_{\mathrm{FU}} \\
\beta \mathrm{x}+\beta \mathrm{FU}=1\end{array}$ & 23.65 & 3.841 & 0.0000 & $\begin{array}{l}\text { Since computed } X^{2}>\text { critical } X^{2} \text { at } 0.05 \text {, this } \\
\text { test implies that individual involved in NTFPs } \\
\text { activities both in the rainforest and savannah } \\
\text { zone respectively do not operate under constant } \\
\text { returns to scale. Since } \beta_{\mathrm{XT}}+\beta_{\mathrm{LD}}<1 \text {, we conclude } \\
\text { that there is decreasing returns to scale in } \\
\text { NTFPs activities. }\end{array}$ \\
\hline
\end{tabular}

\subsubsection{Normalized profit function result for bushmeat}

The result of the estimated equations are presented in Table 4.5.3 and 4.5.4. the coefficients all have the expected theoretical signs. As is theoretically consistent, the coefficients of the prices for labour and fuel are negatively signed as expected while capital and land are highly significant in the profit function. In table $4.5 \mathrm{R} 2$ gave a 63 percent explanation of the variation in the profit level of NTFPs (Bush meat) farmers with significant F-value at 10 percent level. All the coefficients of the variable factors of production gave the expected signs which were negative signifying inverse relationship of these variables with the profit level, and a positive relationship of the fixed variables with the profit level.

The implication of this result is that increased use of variable factors of production will mean decreasing level of profit because these are costs in the production process, while increased use of fixed factors of production implies expansion in the level of production and on variable profit level. These factors of production are significant at 1 percent level.

Table 4.5.3: Joint Estimation of the Normalized Profit Function and Factor Share Equations for Two Variable Inputs of Non-Forest Farmers (Bushmeat) in Oyo State $(n=50)$

\begin{tabular}{|c|c|c|c|c|c|c|c|c|c|}
\hline \multirow[t]{2}{*}{ Variable } & \multirow{2}{*}{$\begin{array}{l}\text { Paramete } \\
\mathrm{r}\end{array}$} & \multirow{2}{*}{$\begin{array}{l}\text { Single } \\
\text { Equation } \\
\text { OLS }\end{array}$} & \multirow{2}{*}{$\begin{array}{l}\text { No } \\
\text { restricti } \\
\text { on } \\
\text { (SURE) }\end{array}$} & \multicolumn{6}{|l|}{ Restriction } \\
\hline & & & & $\begin{array}{l}\text { Profit } \\
\text { Maximizatio } \\
\mathrm{n}(1)\end{array}$ & $\begin{array}{l}\text { Profit Max } \\
+ \text { Dummy } \\
(2)\end{array}$ & $\begin{array}{l}\text { Profit Max + } \\
\text { Profit } \\
\text { Max (3) }\end{array}$ & $\begin{array}{l}\text { Const } \\
\text { Returns + } \\
\text { Profit Max } \\
\text { (4) }\end{array}$ & (5) & (6) \\
\hline $\begin{array}{l}\text { Profit } \\
\text { Function }\end{array}$ & $\begin{array}{l}\text { Note } \\
*= \\
10 \% \\
* *=5 \% \\
* * *=1 \%\end{array}$ & & & & & & & & $\begin{array}{l}*= \\
10 \% \\
* *=5 \% \\
* * *=1 \%\end{array}$ \\
\hline Constant & $\mathrm{L}_{\mathrm{n}} \mathrm{A}^{*}$ & $\begin{array}{l}(3.774) \\
2.864\end{array}$ & $\begin{array}{l}(4.823)^{*} \\
* * \\
2.832\end{array}$ & $\begin{array}{l}(4.541)^{* * * *} \\
2.578\end{array}$ & $\begin{array}{l}(4.905)^{* * * *} \\
2.820\end{array}$ & $\begin{array}{l}(5.078)^{* * *} \\
2.874\end{array}$ & $\begin{array}{l}(4.720)^{* * *} \\
2.769\end{array}$ & $\begin{array}{l}(5.900)^{* *} \\
* \\
3.376\end{array}$ & $\begin{array}{l}(2.240) \\
1.039\end{array}$ \\
\hline Labour & ${ }_{\mathrm{LB}}^{\alpha}{ }^{*}$ & $\begin{array}{l}(-1.765) \\
-0.208^{*}\end{array}$ & $\begin{array}{l}(-0.062) \\
-0.187\end{array}$ & $\begin{array}{l}(-0.248) \\
-0.218\end{array}$ & $\begin{array}{l}(0.062) \\
-0.552\end{array}$ & $\begin{array}{l}(-0.134) \\
-0.117\end{array}$ & $\begin{array}{l}(-0.049) \\
-0.436\end{array}$ & $\begin{array}{l}(0.029) \\
-0.256\end{array}$ & $\begin{array}{l}(-1.440) \\
-0.122\end{array}$ \\
\hline Fuel & $\alpha_{\mathrm{FL}}{ }^{*}$ & $\begin{array}{l}(-2.049)^{*} \\
-0.257\end{array}$ & $\begin{array}{l}(- \\
1.785)^{*} \\
-0.187\end{array}$ & $\begin{array}{l}(-1.480)^{*} \\
-0.152\end{array}$ & $\begin{array}{l}(1.785)^{*} \\
-0.187\end{array}$ & $\begin{array}{l}(-1.89)^{*} \\
-0.183\end{array}$ & $\begin{array}{l}(-2.002)^{*} \\
-0.170\end{array}$ & $\begin{array}{l}(-1.743) \\
-0.183\end{array}$ & $\begin{array}{l}(- \\
2.287)^{* *} \\
* \\
-0.287\end{array}$ \\
\hline Capital & $\beta_{\mathrm{XT}}$ & $\begin{array}{l}(1.954)^{*} \\
0.244\end{array}$ & $\begin{array}{l}(3.620)^{*} \\
* * \\
0.340\end{array}$ & $\begin{array}{l}(3.520)^{* * *} \\
0.330\end{array}$ & $\begin{array}{l}(3.620)^{* * * *} \\
0.340\end{array}$ & $\begin{array}{l}(3.769)^{* * *} \\
0.353\end{array}$ & $\begin{array}{l}(3.709) * * * \\
0.349\end{array}$ & $\begin{array}{l}(3.645)^{* *} \\
* \\
0.343\end{array}$ & $\begin{array}{l}(10.625) \\
* * * \\
0.683\end{array}$ \\
\hline Land & $\beta_{\mathrm{LD}}$ & $\begin{array}{l}(2.251)^{* *} \\
* \\
0.882\end{array}$ & $\begin{array}{l}(7.409)^{*} \\
* * \\
0.697\end{array}$ & $\begin{array}{l}(-0.561) \\
0.494\end{array}$ & $\begin{array}{l}(7.409) * * * \\
0.697\end{array}$ & $\begin{array}{l}(5.984)^{* * * *} \\
0.525\end{array}$ & $\begin{array}{l}(3.660) * * * \\
0.335\end{array}$ & $\begin{array}{l}(3.660)^{* *} \\
* \\
0.335\end{array}$ & $\begin{array}{l}(4.927) \\
* * * \\
-0.316\end{array}$ \\
\hline $\begin{array}{l}\text { Ecologic } \\
\text { al Zone } \\
\text { of }\end{array}$ & $\Delta \mathrm{e}$ & $\begin{array}{l}(-1.437) \\
-0.365\end{array}$ & $\begin{array}{l}(- \\
1.693)^{*} \\
-0.423 \\
\end{array}$ & $\begin{array}{l}(1.626)^{*} \\
0.375\end{array}$ & $\begin{array}{l}(-2.131)^{* *} \\
-0.407\end{array}$ & $\begin{array}{l}(2.278)^{* *} \\
-0.555\end{array}$ & $\begin{array}{l}(0.677) \\
0.159\end{array}$ & $\begin{array}{l}(- \\
4.715)^{* *} \\
*\end{array}$ & $\begin{array}{l}(-2.901) \\
-0.706\end{array}$ \\
\hline
\end{tabular}


Economics of non-timber forest products (NTFPS) in Oyo-state, Nigeria.

\begin{tabular}{|c|c|c|c|c|c|c|c|c|c|}
\hline $\begin{array}{l}\text { farmers } \\
\left(\delta \mathrm{e}^{*}\right) \\
(1=\text { Rain } \\
\text { forest }) \\
(0=\text { Sava } \\
\text { nah) }\end{array}$ & & & & & & & & $(0.983$ & \\
\hline $\begin{array}{l}\text { Factor } \\
\text { share } \\
\text { Equator }\end{array}$ & & $\begin{array}{l}\mathrm{R}^{2}=0.634 \\
\mathrm{R}^{2}=0.524 \\
\mathrm{~F}(6.32)= \\
2.20\end{array}$ & $\begin{array}{l}\mathrm{R}^{2}=0.04 \\
8 \\
\mathrm{R}^{2}=0.19 \\
4\end{array}$ & $\begin{array}{l}\mathrm{R}^{2}=0.094 \\
\mathrm{R}^{2}=0.2464\end{array}$ & $\begin{array}{l}\mathrm{R}^{2}=0.048 \\
\mathrm{R}^{-2}=0.194\end{array}$ & $\begin{array}{l}\mathrm{R}^{2}=0.542 \\
\mathrm{R}^{-2}=0.757\end{array}$ & $\begin{array}{l}\mathrm{R} 2=0.564 \\
\mathrm{R}-2=0.783\end{array}$ & $\begin{array}{l}\mathrm{R} 2=0.220 \\
\mathrm{R}-2=0.91\end{array}$ & $\begin{array}{l}\text { R2 }=0.357 \\
\text { R- } \\
2=0.546\end{array}$ \\
\hline $\begin{array}{l}\text { Labour } \\
\text { Factor } \\
\text { share } \\
\text { Paramet } \\
\text { er for } \\
\text { rainfores } \\
\text { t Zone }\end{array}$ & $\begin{array}{l}*^{* *}{ }_{\mathrm{RF}} \\
{ }_{\mathrm{LB}}\end{array}$ & $\begin{array}{l}(-6.704) \\
* * * \\
-77.615\end{array}$ & $\begin{array}{l}-(6.843) \\
-77.615\end{array}$ & $\begin{array}{l}(-6.638)^{* * *} \\
-71.953\end{array}$ & $\begin{array}{l}(-7.977)^{* * *} \\
-77.833\end{array}$ & $\begin{array}{l}(-0.134) \\
-0.117\end{array}$ & $\begin{array}{l}(-.049) \\
-0.436\end{array}$ & $\begin{array}{l}(- \\
6.843)^{* *} \\
* \\
-77.61\end{array}$ & $\begin{array}{l}(-6.843) \\
* * * \\
-77.615\end{array}$ \\
\hline $\begin{array}{l}\text { Factor } \\
\text { share } \\
\text { paramet } \\
\text { er for } \\
\text { savanna } \\
\text { h zone }\end{array}$ & $\begin{array}{l}{ }^{* *}{ }_{\mathrm{SA}} \\
\alpha_{\mathrm{LB}}\end{array}$ & $\begin{array}{l}(- \\
4.017)^{* *} \\
* \\
-78.454\end{array}$ & $\begin{array}{l}(- \\
4.100)^{*} \\
* * \\
-78.454\end{array}$ & $\begin{array}{l}(-5.696)^{* * * *} \\
-94.568\end{array}$ & $\begin{array}{l}(-7.977)^{* * *} \\
-77.833\end{array}$ & $\begin{array}{l}(-4.406)^{* * *} \\
-71.619\end{array}$ & $\begin{array}{l}(-4.100)^{* * *} \\
-78.45\end{array}$ & $\begin{array}{l}(0.029) \\
-0.256\end{array}$ & $\begin{array}{l}(-4.100) \\
* * * \\
-78.454\end{array}$ \\
\hline $\begin{array}{l}\text { Fuel } \\
\text { Factor } \\
\text { share } \\
\text { paramet } \\
\text { er for } \\
\text { rainfores } \\
\text { t zone }\end{array}$ & $\begin{array}{l}*_{\mathrm{RF}}^{*}{ }_{\mathrm{RF}} \\
{ }_{\mathrm{FU}}\end{array}$ & $\begin{array}{l}(- \\
4.038)^{* *} \\
* \\
-6.174\end{array}$ & $\begin{array}{l}(- \\
4.121)^{*} \\
* * \\
-6.174\end{array}$ & $\begin{array}{l}(-3.828)^{* * *} \\
-5.567\end{array}$ & $\begin{array}{l}(-4.630)^{* * *} \\
-5.966\end{array}$ & $\begin{array}{l}(1.789)^{*} \\
-0.183\end{array}$ & $\begin{array}{l}(-1.621) \\
-0.170\end{array}$ & $\begin{array}{l}(- \\
4.121)^{* *} \\
* \\
-6.174\end{array}$ & $\begin{array}{l}(-4.121) \\
* * * \\
-6.174\end{array}$ \\
\hline $\begin{array}{l}\text { Factor } \\
\text { share } \\
\text { paramet } \\
\text { er for } \\
\text { savanna } \\
\text { h zone }\end{array}$ & $\begin{array}{l}{ }^{* *}{ }_{\mathrm{SA}} \\
{ }_{\mathrm{F}}\end{array}$ & $\begin{array}{l}(- \\
2.084)^{* *} \\
-5.375\end{array}$ & $\begin{array}{l}(- \\
2.127)^{*} \\
* \\
-5.375\end{array}$ & $\begin{array}{l}(-6.072)^{* * *} \\
-7.102\end{array}$ & $\begin{array}{l}(-4.630)^{* *} \\
-5.966\end{array}$ & $\begin{array}{l}(-2.033)^{* *} \\
-4.642\end{array}$ & $\begin{array}{l}(-2.127)^{* *} \\
-5.375\end{array}$ & $\begin{array}{l}(1.743)^{*} \\
-0.183\end{array}$ & $\begin{array}{l}(-2.127) \\
* * \\
-5.275\end{array}$ \\
\hline
\end{tabular}

Table 4.5.4: Statistical tests of Hypothesis on differences in efficiency between NTFPs users is Rejected in the Rainforest Zone and Savannah zone respectively (Bushmeat)

\begin{tabular}{|c|c|c|c|c|c|}
\hline Hypothesis & Tested & $\begin{array}{l}\text { Computed } \\
X^{2}\end{array}$ & $\begin{array}{l}\text { Critical } \\
X^{2}\end{array}$ & P-Value & Interpretation \\
\hline Hypothesis 1 & $\delta_{\mathrm{RF}}=0$ & 2.8675 & 3.841 & 0.09 & $\begin{array}{l}\text { Since computed } \mathrm{X}^{2}<\text { critical } \mathrm{X}^{2} \text { at } \\
0.05 \text {, this test implies that the null } \\
\text { hypothesis is greater and we } \\
\text { conclude that economic efficiency } \\
\text { (technical and prize or allocative } \\
\text { efficiency of those involved in } \\
\text { NTFPs activities in both rainforest } \\
\text { and savannah are the same. }\end{array}$ \\
\hline Hypothesis 2 & $\begin{array}{l}\text { **SA } \\
* * \mathrm{RF}=\alpha \mathrm{LB} * * \mathrm{SA} \\
\alpha \mathrm{LB} * * \mathrm{RF}=\alpha \mathrm{FU} \\
\alpha \mathrm{FU}\end{array}$ & 0.09 & 5.991 & 0.95 & $\begin{array}{l}\text { Since computed } \mathrm{X}^{2}<\text { critical } \mathrm{X} 2 \text { at } \\
0.05 \text {, this test implies that the price } \\
\text { or allocative efficiency of } \\
\text { individuals involved in NTFPs } \\
\text { activities in rainforest and } \\
\text { savannah zone are the same.i.e } \\
\text { they equate the value of marginal } \\
\text { product of the variable factors to } \\
\text { their opportunity costs. }\end{array}$ \\
\hline Hypothesis 3 & $\begin{array}{l}\delta_{\mathrm{RF}}{ }^{*}=0 \\
* * \mathrm{RF}=\alpha_{\mathrm{LB}}{ }^{*} \\
\alpha_{\mathrm{LB}}{ }^{* *} \mathrm{RF}=\alpha_{\mathrm{FU}}{ }^{*} \\
\alpha_{\mathrm{FU}}\end{array}$ & 51.2 & 7.815 & 0.00 & $\begin{array}{l}\text { Since computed } \mathrm{X}^{2}>\text { critical } \mathrm{X}^{2} \text { at } \\
0.05 \text {, this implies that there is } \\
\text { inequality of relative technical and } \\
\text { price efficiency jointly between } \\
\text { rainforest and savannah users of } \\
\text { NTFPs. }\end{array}$ \\
\hline Hypothesis 4 & $\begin{array}{l}* * \mathrm{RF}=\alpha_{\mathrm{LB}}{ }^{*} \\
\alpha_{\mathrm{LB}}^{* *} \mathrm{RF}=\alpha_{\mathrm{FU}}{ }^{*} \\
\alpha_{\mathrm{FU}}\end{array}$ & 50.7 & 5.991 & 0.00 & $\begin{array}{l}\text { Since computed } \mathrm{X}^{2}>\text { critical } \mathrm{X}^{2} \text { at } \\
0.05 \text {, this test implies that those } \\
\text { involved in NTFPs activities in the } \\
\text { Rainforest zone do not have } \\
\text { absolute allocative or price } \\
\text { efficiency. }\end{array}$ \\
\hline Hypothesis 5 & $\begin{aligned} * * \mathrm{SA} & =\alpha_{\mathrm{LB}}{ }^{*} \\
\alpha_{\mathrm{LB}} * \mathrm{SA} & =\alpha_{\mathrm{FU}}{ }^{*}\end{aligned}$ & 17.4 & 5.991 & 0.0002 & $\begin{array}{l}\text { Since computed } X^{2}>\text { critical } X^{2} \text { at } \\
0.05 \text {, this test implies that those }\end{array}$ \\
\hline
\end{tabular}




\begin{tabular}{|c|c|c|}
\hline & $\alpha_{\mathrm{FU}}$ & $\begin{array}{l}\text { involved in NTFPs activities in the } \\
\text { Savannah zone do not have } \\
\text { absolute allocative or price } \\
\text { efficiency. Savannah NTFPs users } \\
\text { do not have absolute allocative } \\
\text { efficiency. }\end{array}$ \\
\hline Hypothesis 6 & 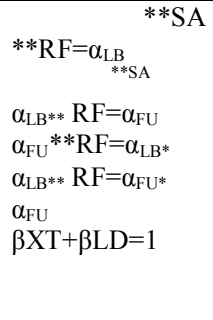 & $\begin{array}{l}\text { Since computed } \mathrm{X}^{2}>\text { critical } \mathrm{X}^{2} \text { at } \\
0.05, \text { this test implies that } \\
\text { individuals zones involved in } \\
\text { NTFPs activities in both rainforest } \\
\text { and Savannah zone respectively, } \\
\text { do not operate under constant } \\
\text { returns to scale. Since, } \beta X T+\beta L D= \\
0.683+0.316=0.99 \text { we conclude } \\
\text { that there is decreasing returns to } \\
\text { scale in NTFPs activities.. }\end{array}$ \\
\hline
\end{tabular}

Table 4.6: Relative Productivity effects of production factors used by NTFPs Users (rainforest and savannah) in Oyo State, 2000. Indirect Production elasticity estimates derived from the dual profit function (Bushmeat)

\begin{tabular}{|l|l|l|}
\hline Parameter & Indirect Estimates & \\
\hline Production factor & $\alpha_{\mathrm{LB}}{ }^{*}=\alpha_{\mathrm{LB}}$ & $\alpha_{\mathrm{LB}}{ }^{*}=\alpha_{\mathrm{LB}} * *, \beta_{\mathrm{LD}}+\beta_{\mathrm{LD}}=1$ \\
& 1 Restriction & Restrictions \\
\hline Labour $\alpha_{\mathrm{LB}}$ & -0.15 & -0.089 \\
Fuel $\alpha_{\mathrm{FU}}$ & -0.11 & -0.139 \\
Tools $\beta_{\mathrm{XT}}$ & 0.24 & 0.271 \\
Land $\beta_{\mathrm{LD}}$ & 0.35 & 0.40 \\
Sum $\alpha_{\mathrm{j}}{ }^{\mathrm{s}} \beta_{\mathrm{j}}, \mathrm{s}$ & 0.86 & 0.90 \\
\hline
\end{tabular}

Source: Computed from survey data 2003.

Table 4.7: Indirect Production Estimates for Fuel Wood

\begin{tabular}{|l|l|l|}
\hline Parameter & Indirect Estimates & \\
\hline Production factor & $\alpha_{\mathrm{LB}} * \alpha_{\mathrm{LB}}$ & $\alpha_{\mathrm{LB}}{ }^{*}=\alpha_{\mathrm{LB}} * *, \beta_{\mathrm{LD}}+\beta_{\mathrm{LD}}=1$ \\
& 1 Restriction & -0.278 \\
\hline Labour $\alpha_{\mathrm{LB}}$ & -0.20 & -0.375 \\
Fuel $\alpha_{\mathrm{FU}}$ & -0.33 & 0.117 \\
Tools $\beta_{\mathrm{XT}}$ & 0.197 & 0.20 \\
Land $\beta_{\mathrm{LD}}$ & 0.182 & 0.974 \\
Sum $\alpha_{\mathrm{j}}{ }^{\mathrm{s}} \beta_{\mathrm{j}}{ }^{, \mathrm{s}}$ & 0.902 & \\
\hline
\end{tabular}

Source: Computed from survey data 2003.

The estimates in the table 4.6 and 4.7 shows that an increase of labour cost by 10 percent will reduce the profit of bush meat users by 1.5 percent. Similarly a 10 percent increase in fuel price will reduce profit by 1.1 percent. However, an increase of farm tools by 10 percent will increase profit of bush meat by 2.41 percent, while an increase In land by 10 percent, will increase the profit level by 3.5 percent. This shows that labour is the most limiting factor in bush meat trade.

The estimates for the fuel wood shows that a 10 percent increase in labour cost will reduce the profit level by $2 \%$ awhile it will reduce it 3.3 percent as a result of 10 percent increase in fuel cost. However, a 10 percent increase in fixed tools and land will increase the profit by 1.97 and 1.82 percent respectively. Here, fuel is the most limiting factor in fuel wood trade so effort should be aimed at reducing transportation cost and since labour is the most limiting factor in Bushmeat trade, technologies that enhance productivity of labour is likely to achieve significant positive effects on Bushmeat trade.

The result from the normalized profit function also shows that for hypothesis 2 tested for both fuelwood and Bushmeat, there is equal price or allocative efficiency for NTFPs users in the two zones (rainforest and Savannah). The implication is that they are profit maximizers i.e they equate the value of their marginal product of labour to wage rate and the value of marginal plroduct of fuel price to the same degree. However, hypothesis 5 when tested there is difference in the result for the two zones. For fuel wood, savannah NTFPs users have absolute allocative efficiency while savannah NTFPs users for bushmeat do not have. The implication is that there is sustainability for fuelwood in the savannah zone. Government should invest in the development of fuelwood/charcoal activities in the savannah zone. 
Economics of non-timber forest products (NTFPs) in Oyo-state, Nigeria.

5.1 Summary.

\section{Summary, Recommendations And Conclusion.}

The results presented in this thesis were focused on the objectives defined in chapter one which first to generally the economic contributions of the major non-timber forest product or the livelihoods of rural communities in Oyo State and specifically to determine

(i) the socio-economic characteristics of NTFP users that influence their activities e.g. gathering, processing and marketing

(ii) the costs and returns of the major NTFPs in the study area

(iii) the influence of ecological zone on the efficiency/profitability of NTFPs users

The socio-economic characteristics of NTFP users that affect their profitability include their age, family size, sex marital status, experience, educational status, proximity etc.

The average of NTFP users area is 42-years, average family size is seven persons the average experience of NTFP user is less than 10 years. 31.3 percent of the users had to formal education. The socioeconomic features also revealed that 52.7 percent are Christians while $41.3 \%$ are Muslims.

The regression analysis shows that 44.9 percent of the total variation in the income of non-timber forest product users is affected by the significant factors like age, other income sources, expenditure on NTFPs, ecological zone, religion, major occupation, prices etc at 1 percent. The coefficients of these variables also show positive signs which implies relationship with income e.g. the higher the price of NTFP, the higher the income.

The gross margin analysis was adopted to determine costs and benefits incurred and realized by NTFPs users. The results shows that the average cost/seller is N6,827.57 as against an average of N15,655.11 as revenue/benefit.

The users gross margin is N8,827.64 per month which indicates that NTFPs business is profitable if encouraged by government and private sectors.

The gini coefficient analysis on the other hand shows that there is inequality in income distribution in NTFPs trade in the study area.

The profit function approach was adopted to obtain the various demand /output functions. These are presented in the relevant tables.

The results for both fuelwood and bushmeat show that all the coefficients of the variable factors of production e.g. labour and fuel gave the expected signs which were negative signifying an inverse relationship with the fixed variables e.g. land and capital. The implication of this result is that increased use of variable factors of production will mean decreasing the level of profit because these are costs in the production process, , while increased use of fixed factors of production implies expansion in the level of production and on profit level.

The result from the indirect production elasticity shows that an increase of labour cost by 10 percent will reduce the profit of bush meat by 1.5 percent whereas it will reduce fuel price by 1.1 percent. In the case of fuel wood a 10 percent increase in labour cost will reduce the profit level by 2 percent while an increase of 10 percent in fuel will reduce the profit by 3.3 percent. This result that in the case of bush meat, labour is the most limiting factor whereas it is fuel that in the case of bushmeat, labour is the most limiting factor whereas it is fuel in the case off fuelwood because fuel is needed for transportation over long distance. The result from testing the various hypothesis also shows that there is equal price allocative efficiency between NTFPs users in both savannah and rainforest for both fuelwood and bushmeat i.e NTFP users are profit maximizes.

Also, the result from testing hypothesis 5 shows that savannah NTFPs users have absolute allocative efficiency for fuelwood whereas users do not have absolute allocative efficiency for bushmeat. The implication is that fuelwood is sustainable in the savannah zone whereas bushmeat is not. Government should therefore encourage the development of fuelwood production and marketing sustainably.

The result also shows that there is decreasing returns to scale for NTFPs users in the study area.

\subsection{Recommendations and Conclusion.}

This study stresses the importance of NTFPs and their sustainable management. As mentioned in the study NTFPs comprise a wide range of forest products such as plants, fruits, nuts, roots, species, gums, oils, mushrooms, miscellaneous exudates such as resins, latex, essential oils, tannins and others. The following are recommended.

(i) The government should encourage the development of participative programmes involving local people for the evaluation of NTFP resources base and planning the management of resources for the sustainable production, harvesting and use of key NTFP and incorporate these programmes into their policies.

(ii) More attention should be given to Research and Development for the rational production, trade, marketing and use of NTFPs to the development of new market opportunity, improve the tenurial rights of local people producers and users and adopt measures for sustainable harvesting specially in fragile ecological zone. 
(iii) Knowing the crucial role played by NTFPs in rural economies of developing Nigeria and developed countries at various levels in providing food security, subsistence, income and employment generation, commercialization and use, there should proper accounting for these large contribution of NTFPs at the local, national and international levels and specific policies for most of the NTFPs should be made available.

(iv) The rights of local people should be properly protected through the establishment of sound legislation, the development of adequate education programmes and the establishment of incentives for the promotion of NTFP.

(v) The government should provide credit facilities through commercial banks to encourage the youths to be engaged in NTFP business since it is profitable and sustainable.

(vi) The government should provide adequate infrastructure vis-as-vis good road network, electricity, water etc. in this way, increase in the cost of processing, transportation will be reduced. As a consequence the NTFPs users will make enough profit to cater for the immediate needs of their families such as payment of school fees.

It is obvious that non-timber forest products contribute immensely to the socio-economic and cultural lives of Nigerians. Unfortunately, many of such species are either presently under threat, endangered or extinction a number of cases, as a result of over use, misuse and destructive utilization.

Factors such as demographic, economic, poor management, ecological problems and urban and industrial development are responsible for this observation. In order to ensure the sustainability of these resources, forest management plans should be reviewed and update. Forest communities should be involved in forest management while economic and conservation measure should be applied by the government. Forest administration should necessarily accept and appropriate that the life of the local communities, living and within forest, revolve around such forest (Adeyoju 1975; Ajai Kaul, 1996).

Non-timber forest products are gradually assuming local, national and global economic importance with the realization of their potential, enormous, yet unquantified contribution to economies.

It is also obvious that government have only a passing interest in this segment of the forestry sub-sector as the market is dominated by private people at the various levels/domains along the marketing chain. With the gradual downsizing of government interest in the productive sector of economies, private and community state in NTFPs production and marketing should be strengthened. This spears the way forward to developing the huge untapped NTFPs trade.

\section{Journal paper}

\section{References}

[1]. FAO, Non-wood forest products: the way ahead. fao forestry paper 97 food and agricultural organization of the un. 1991. 38 .

[2]. FAO Community forestry note 1 (1991): forest, trees and people.

[3]. J.C. Okafor, Trees for food and fodder in the savannah areas of nigeria.the international tree crops journal 1, 1980, $131-141$.

[4]. L. Popoola et al, Farmers priority in multipurpose tree and shrubs species for agroforestry in the humid lowlands of nigeria. journals of tropical forest resources, vol. (12) 1996, 16-31.

Books

[5]. S.K. Adeyoju, Forestry and the Nigerian economy (Ibadan University Press

[6]. University Of Ibadan, Nigeria 1975). 308

Thesis

[7]. A.F. Nkwatoh, Evaluation of trade on non-timber forest products in the Egagbam forest reserve of South West Cameroon University Of Ibadan 2000167.

\section{Proceedings}

[8]. J.C. Okafor "Strategies for development of fruit tree and Ntfps in Nigeria

[9]. $24^{\text {th }}$ annual conference of fan, 1995.

[10]. L. Popoola And, S.A. Oluwana, Marketing of non-timber forest production in Nigeria. paper presented at colloquimon biodiversity (rain forest ecosystem of Nigeria) by FEPA - NAAB linkage centre for forest conservation and biodiversity 8-10 1998 21

\section{Working Papers}

[11]. J.E.M. Arnold. Non-farm employment in small scale forest-based enterprises policy and environmental issues. EPAT/Mucia Working Paper No. 11 Madison. University Of Whilconson 1994.

[12]. J.K. E Gunjobi, Potential use of non-wood forest resources at the Omo biosphere reserve in southern Nigeria; consultancy report on UNESCO Nairobi 1996 (33).

[13]. J.Falconer, J. FRMP project working paper on the use and trade of ntfps and the management and programme development. Oxford, u.k. 1991

[14]. J.C. Okafor Et Al. "Non-timber forest products-draft report prepared for the national tropical forestry action programme (ntfap) fomecu abuja- Nigeria, 1994

[15]. D.O. Ladipo, Collection and conservation of the genetic resources of irvingia gabmentis in west and central Africa, 1995, ICR AF. 